\title{
Immunohistochemistry for diagnosis and prognosis of breast cancer: a review
}

\section{T. Bonacho, F. Rodrigues \& J. Liberal}

To cite this article: T. Bonacho, F. Rodrigues \& J. Liberal (2019): Immunohistochemistry for diagnosis and prognosis of breast cancer: a review, Biotechnic \& Histochemistry, DOI: 10.1080/10520295.2019.1651901

To link to this article: https://doi.org/10.1080/10520295.2019.1651901

曲 Published online: 10 Sep 2019.

Submit your article to this journal 준

Ц Article views: 76

Q View related articles ¿

View Crossmark data $[\pi$ 


\title{
Immunohistochemistry for diagnosis and prognosis of breast cancer: a review
}

\author{
T. Bonacho ${ }^{a}$ F. Rodrigues (D) ${ }^{a, b, c}$, and J. Liberal $\mathbb{D D}^{\mathrm{a}, \mathrm{b}}$
}

aEscola Superior de Saúde Dr. Lopes Dias, Instituto Politécnico de Castelo Branco, Castelo Branco, Portugal; b Qualidade de Vida no Mundo Rural (QRural), Instituto Politécnico de Castelo Branco, Castelo Branco, Portugal; 'Sport, Health \& Exercise Unit (SHERU), Instituto Politécnico de Castelo Branco, Castelo Branco, Portugal

\begin{abstract}
Breast cancer is the most prevalent malignant tumor and main oncologic cause of mortality in women. Although most diagnosis of breast pathology is accomplished using hematoxylin and eosin stained sections, some cases require immunohistochemistry for proper evaluation. We investigated the latter cases including distinctions between ductal and lobular carcinoma, in situ and invasive carcinoma, typical ductal hyperplasia and atypical ductal hyperplasia/ductal carcinoma in situ, papillary and spindle cell lesion assessment, metastasis evaluation, and assessment of prognostic and therapy markers. E-cadherin is used to differentiate ductal and lobular carcinoma; 34ßE12, CK8, p120 catenin and $\beta$-catenin also produce consistent results. Myoepithelial cell (MEC) stains are used to evaluate in situ and invasive carcinoma; calponin, smooth muscle myosin heavy chain and p63 are sensitive/ specific markers. $34 \beta E 12$ and $C K 5 / 6$ are positive in ductal hyperplasia, which enables its differentiation from atypical ductal hyperplasia and ductal carcinoma in situ. CK 5/6, ER and MEC markers are consistent options for evaluating papillary lesions. Spindle cell lesions can be assessed using $\beta$-catenin, SMA, CD34, p63, CKs and hormone receptors. It is important to differentiate primary carcinomas from metastases; the most commonly used markers to identify breast origin include mammaglobin, GCDFP-15, GATA3 and ER, although none of these is completely sensitive or specific. Immunohistochemistry can be used to evaluate central prognostic and predictive factors including molecular subtypes, HER2, hormone receptors, proliferation markers (Ki-67) and lymph-vascular invasion markers including ERG, CD31, CD34, factor VIII and podoplanin. Owing to the complexity of mammary lesions, diagnosis also depends on each particular situation, evaluation of cytological characteristics revealed by immunochemistry and correlation with histological findings.
\end{abstract}

\section{KEYWORDS}

Breast; cancer; diagnosis; immunohistochemistry; prognosis; review
Breast cancer is the most prevalent malignant tumor and the main oncologic cause of mortality in women in both developed and developing countries (Jemal et al. 2011). Risk factors that contribute to high incidence include unhealthy lifestyle, long time fertility, use of hormone based contraceptives, hormone replacement therapy, alcohol consumption, obesity after menopause and physical inactivity (Ghoncheh et al. 2016). Early diagnosis is vital for identifying high risk cases and providing the most appropriate treatment (Anothaisintawee et al. 2013).

Glandular and ductal breast tissue comprise three cell types: myoepithelial cells (MEC), basal cells and luminal cells. Each type expresses different protein subtypes, which are described in Table 1 (Lerwill 2004; Yeh I-T 2008; Liu 2014; Zaha 2014).

\section{Immunohistochemistry (IHC) for diagnosis}

\section{Ductal carcinoma vs. lobular carcinoma}

Most invasive and in situ ductal and lobular carcinomas are identified easily using hematoxylin and eosin $(\mathrm{H} \&$ E) stained sections. Some cases exhibit ambiguous morphological features, however, and IHC can be helpful for classifying the cancer. Accurate pathological classification is vital from a therapeutic standpoint, because ductal carcinoma in situ (DCIS) and lobular carcinoma in situ (LCIS) are treated differently (Khazai and Rosa 2015; Peng et al. 2017).

The therapeutic goal for DCIS is to eradicate it by surgery and/or radiation, because it is a nonobligate precursor of invasive carcinoma (Gorringe et al. 2017). LCIS can be a risk factor for and a nonobligate precursor

CONTACT Joana Liberal joanaliberal@gmail.com Escola Superior de Saúde Dr. Lopes Dias, Instituto Politécnico de Castelo Branco, Campus da Talagueira, Avenida do Empresário, Castelo Branco 6000-767, Portugal

(c) 2019 The Biological Stain Commission 
Table 1. Proteins expressed by different cell types in breast.

\section{Myoepithelial cells}

SMA, calponin, p63, S100, CD10, SMMHC, maspin, P-cadherin, WT1 and basal types CKs (CK5/6, CK14, CK17)

Luminal cells

CK 7, CK8, CK18, CK19, EMA, MFGM, a-lactalbumin, ER, PR

Basal cells

CK5/6, CK14, CK17

SMA, smooth muscle actin; SMMHC, smooth muscle myosin heavy chain WT1, Wilm's tumor 1 protein; CK, cytokeratin; EMA, epithelial membrane antigen; MFGM, milk fat globule membrane antigen; $E R$, estrogen receptor; $\mathrm{PR}$, progesterone.

of invasive carcinoma. Management is controversial and depends on the characteristics of each case, but long term clinical follow-up, with or without chemoprophylaxis, usually is recommended (Lakhani et al. 2012; Ginter and D'Alfonso 2017). Despite being biologically, pathologically and clinically different, invasive lobular and ductal carcinomas are treated similarly owing to prognostic and predictive factors (Jacobs et al. 2015).

E-cadherin is the most common marker for differentiating ductal and lobular carcinomas. For the majority of ductal carcinomas, E-cadherin exhibits membrane staining. By contrast, most lobular carcinomas exhibit complete loss of membrane E-cadherin expression (Acs et al. 2001; Dabbs et al. 2007a; Singhai et al. 2011; Li et al. 2014), although aberrant staining may be found in approximately $10-16 \%$ of cases (Lakhani et al. 2012).

For high molecular weight cytokeratin (HMWCK), $34 \beta E 12$ can be used together with E-cadherin, especially in cases where E-cadherin staining is inconclusive. Bratthauer et al. (2002) reported perinuclear cytoplasmic staining in lobular neoplastic cases; immunostaining was absent or reduced in ductal neoplastic cases. Basal ductal carcinoma was the exception; this was positive for $34 \beta E 12$ (Thike et al. 2010).

Despite being positive in ductal and lobular carcinomas, CK8 also can be used, because the staining pattern is different. Lehr et al. (2000) reported predominantly peripheral cytoplasmic staining in ductal carcinoma in addition to molding of adjacent tumor cells to each other to form tumor cell clusters. Perinuclear staining was observed in cases of lobular carcinoma.

p120 Catenin exhibits intense membrane staining in ductal carcinoma and strong diffuse cytoplasmic staining in lobular carcinoma (Dabbs et al. 2007a, 2007b; Li et al. 2014). $\beta$-Catenin, a membrane stain with or without cytoplasmic expression, was observed in ductal carcinoma, whereas lobular carcinoma exhibited no membrane staining and a granular cytoplasmic pattern (Dabbs et al. 2007a; Karabacak et al. 2011).

\section{In situ carcinoma vs. invasive carcinoma}

In situ carcinoma is defined as proliferation of malignant epithelial cells that are restrained by the basement membrane (Ward et al. 2015). By contrast, invasive carcinoma penetrates the basement membrane and invades the surrounding stroma (Zhao et al. 2014). Histologically, the main characteristic of invasion is the lack of MECs around the lesion (Rosen 2008). Detection of presence or absence of MECs in $\mathrm{H} \& \mathrm{E}$ stained sections can be challenging; therefore, IHC is a valuable tool for detecting small foci of invasion (Liu 2014). Among the MEC markers listed above, calponin, smooth muscle myosin heavy chain (SMMHC) and p63 are the most specific and sensitive. Calponin and SMMHC exhibit a linear cytoplasmic pattern with gaps in MECs in in situ carcinomas; invasive carcinomas are characterized by absence of expression for calponin and SMMHC. P63 immunostaining for in situ carcinoma is characterized by a linear dot-like nuclear pattern, focally discontinuous, in MECs; expression for p63 is absent in invasive carcinomas. The combination of calponin, SMMHC and $\mathrm{p} 63$ produces cytoplasmic and nuclear staining and can be a valuable option (Yeh I-T 2008; Liu 2014). These markers also can be useful for differential diagnosis of invasive carcinoma from other conditions that mimic infiltration, such as sclerosing adenosis and radial scars (Liu 2014; Zaha 2014). By contrast, other uncertain situations may occur when certain invasive carcinomas resemble carcinoma in situ, such as solid papillary and cribriform carcinomas (Lerwill 2004). Another marker, p75 neurotrophin receptor, exhibits immunoreactivity similar to SMMHC and p63; it is consistently positive for MECs (Popnikolov et al. 2005).

\section{Usual ductal hyperplasia (UDH) vs. atypical ductal hyperplasia (ADH) and DCIS}

Accurate classification of UDH (benign lesion), ADH (borderline lesion) and DCIS (pre-invasive lesion) is important, because an excision follows in $\mathrm{ADH}$ and DCIS cases, while clinical follow-up is suitable for patients with UDH (Zhao et al. 2014). Distinction generally can be made using $\mathrm{H} \& \mathrm{E}$ stained sections due to the distinct morphological features of each. $\mathrm{UDH}$ has greater cell heterogeneity with nuclear overlapping, indistinct cell margins and variations of cell shape and size. By contrast, ADH and DCIS exhibit a uniform cell population with distinct cell margins organized around punched out spaces (Dirbas 2011). 
In cases of uncertainty, IHC can give greater emphasis to the differentiating traits.

Application of a breast marker cocktail consisting of basal cell, MEC and luminal cell markers produces a mosaic staining pattern in cases of UDH, which reflects the polymorphic proliferation characteristics of this condition. No immunostaining of basal/ myoepithelial markers is observed in ADH and DCIS, because these markers exhibit clonal proliferation of luminal cells (Abdel-Fatah et al. 2008). Otterbach et al. (2000) reported that CK 5/6 produced strong expression in $87.6 \%$ of UDH cases. Lack of expression was observed in $47.4 \%$ of $\mathrm{ADH}$ cases, while $43.1 \%$ exhibited only a few immunopositive cells. Only $3.7 \%$ of DCIS cases exhibited CK 5/6 staining. Moinfar et al. (1999) reported a strong reaction for $34 \beta \mathrm{E} 12$ in all $\mathrm{UDH}$ cases by contrast to absent to weak staining in 80 and $90 \%$ of $\mathrm{ADH}$ and DCIS cases, respectively. Lacroix-Triki et al. (2003) reported that CK5/6 exhibits less reactivity than $34 \beta E 12$ in DCIS cases; therefore, a clearer interpretation may be achieved using the latter marker for differential diagnosis.

Estrogen receptors (ER) and progesterone receptors (PR), exhibit scattered nuclear immunostaining in UDH cases, while a diffuse nuclear pattern is observed in $\mathrm{ADH} /$ DCIS cases (Lin et al. 2015). Martinez et al. (2016) reported that use of ER together with CK5 increased the sensitivity of the differentiation of UDH from ADH and DCIS compared to using these two markers separately.

\section{Evaluation of papillary lesions}

Fibrovascular cores that support epithelial proliferation are characteristic of papillary lesions of the breast (Rakha and Ellis 2018). This heterogeneous group of neoplasms includes benign intraductal papilloma (IDP), atypical papilloma, IDP with DCIS, papillary DCIS, papillary carcinoma variants - encapsulated papillary carcinoma (EPC) and solid papillary carcinoma (SPC). Recognition of papillary architecture generally is clear, but accurate subclassification frequently can be challenging (Jorns 2016). The most commonly used immunostains include HMWCKs (CK5/6, CK14, 34ßE12), MEC markers (p63, SMMHC, SMA, CK14, CD10, S100, calponin), neuroendocrine markers (chromogranin, synaptophysin) and hormone receptors (HR) ER and PR (Otsuki et al. 2007; Kuroda et al. 2014; Tse et al. 2014; Wei 2016).

One of the difficulties with diagnosis of papillary lesions using $\mathrm{H} \& \mathrm{E}$ staining is discrimination of IDP from atypical papilloma. IDP is a benign, confined proliferation with fibrovascular cores surrounded by an internal myoepithelial layer and an external epithelial layer. The epithelium can exhibit UDH and/or apocrine metaplasia
(Jorns 2016). There is no uniform definition for atypical papilloma. The term, atypical papilloma, generally is used when a case fails to meet DCIS criteria or to indicate the possible presence of a neoplastic component in a papilloma (Agoumi et al. 2016). Diagnostic problems may occur when there is an IDP with UDH, which may cause uncertainty in cases of atypia (Simpson et al. 2005). CK $5 / 6$ and ER immunostaining can be used to clarify the pathology. CK $5 / 6$ is not expressed in cases of atypia, which distinguishes it from the strong staining pattern of UDH (Nofech-mozes et al. 2008). ER exhibits a strong diffuse expression in atypical papilloma, whereas weaker staining is observed with IDP with UDH (Grin et al. 2009). One possible problem with interpretation is nonexpression of CK 5/6 in IDP apocrine metaplasia, which may cause diagnostic errors (Nofech-mozes et al. 2008).

The immunostaining patterns of CK5/6 and ER are equal; for atypical papilloma and IDP with DCIS, CK5/6 is unstained and ER is stained diffusely (Ichihara et al. 2007). Therefore, discrimination of atypical papilloma from IDP with DCIS should be based on the different sizes of the lesions. Atypical papilloma usually is $<0.3 \mathrm{~cm}$, while IDP with DCIS generally is $>0.3 \mathrm{~cm}$. IHC can be useful by accentuating the abnormal area to help determine the size of both lesions (Lakhani et al. 2012).

A distinctive feature of IDP with DCIS is the existence of recognizable benign cells, which contrasts with the malignant epithelium throughout the papillary DCIS and papillary carcinoma lesions. MEC markers stain within the papillae and at the periphery of the lesion in IDP with DCIS cases (Jorns 2016). On the other hand, papillary DCIS exhibits only peripheral expression (Tse et al. 2007). Although considered an in situ lesion, EPC generally lacks MECs within papillae; at the periphery, they are absent in $>85 \%$ of cases (Rakha et al. 2011). Some investigators have considered EPC a subtype of invasive carcinoma with good prognosis (Grabowski et al. 2008; Rakha et al. 2012) or a lesion in transition (Hill and Yeh 2005; Esposito et al. 2009). A diffuse ER staining pattern is observed for EPC, while CK5/6 is negative (Agoumi et al. 2016). SPC also is considered an in situ lesion. Absence of MECs within papillae is characteristic of this condition; at the periphery, they are absent in $>70 \%$ of cases (Rakha and Ellis 2018). Therefore, it has been suggested that SPC also represents a subtype of invasive carcinoma with a good prognosis (Jorns 2016). CK 5/6 also is negative for SPC; the neuroendocrine markers, chromogranin and synaptophysin, frequently are positive (Rabban et al. 2006; Otsuki et al. 2007).

IDP with abundant sclerosis can appear infiltrative and may lead to false diagnosis of invasion. Because the myoepithelium usually remains in the sclerotic foci of benign cases, MEC markers can be useful for 
highlighting them (Mugler et al. 2007). Similarly, these markers can be used to detect invasion or pseudoinvasion in papillary DCIS, because they are absent in cases of true invasion (Tse et al. 2007). In papillary carcinomas, however, pseudo-invasion and true invasion can be difficult to distinguish in cases of dense sclerosis, and MEC markers are not useful, because they generally are not expressed in papillary and invasive carcinomas (Mugler et al. 2007; Dewar et al. 2011; Rakha et al. 2011).

Core needle biopsy commonly is used for diagnosis of papillary lesions. Diagnostic inaccuracy may occur, however, due to insufficient sampling, sample unsuitability or unclear histopathologic characteristics (Wen and Cheng 2013). Cases identified as nonmalignant may in fact be malignant; this has been reported at a rate of $15.7 \%$ (Wen and Cheng 2013). Overestimation also may occur, although less frequently, i.e., $5-10 \%$ (Tse 2017). Because surgical excision should be performed in cases of atypia/malignancy, whereas imaging follow-up is recommended for benign lesions, an accurate distinction is mandatory (Grin et al. 2009). The combined immunoprofile of CK5-low/ER-high is consistent with atypical/malignant lesions (specificity and sensitivity, 100 and 93\%, respectively). CK5-high/ERlow profile is consistent with benign cases (specificity and sensitivity, 93 and $100 \%$, respectively). Together with the morphological features, these profiles can be helpful for interpreting papillary lesions in core needle biopsy (Grin et al. 2009).

\section{Evaluation of spindle cell lesions}

Although myoepithelial and luminal cells can exhibit spindle shapes, spindle cell lesions of the breast generally refer to mesenchymal or mesenchymal-like cells that exhibit stretched and elongated cytoplasm (Tan and Sahin 2017). Spindle cell lesions include a wide spectrum of lesions ranging from low to high grade (Magro 2017). The most common low grade lesions include fibromatosis, benign and borderline phyllodes tumor, pseudoangiomatous stromal hyperplasia (PASH) and myofibroblastoma. Spindle cell metaplastic carcinoma and malignant phyllodes tumors are the most common high grade lesions (Charu and Cimino-Mathews 2017; Tay and Tan 2017).

Limited sampling by core needle biopsy together with overlapping morphological features among some lesions can cause diagnostic difficulties. In these cases, IHC may be a valuable tool (Rakha et al. 2016). Accurate diagnosis is vital owing to different management implications; for metaplastic carcinoma, neoadjuvant chemotherapy may be used, while in other lesions, such as myofibroblastoma and malignant phyllodes tumor, neoadjuvant chemotherapy plays no significant role (Charu and Cimino-Mathews 2017).

Fibromatosis is a benign fibroblastic and myofibroblastic proliferation characterized by long intersecting fascicles of spindle cells with wavy and elongated nuclei in collagenous stroma. Although this is a locally aggressive lesion, it does not metastasize (Tan and Sahin 2017). $\beta$-Catenin exhibits nuclear reactivity in $70-80 \%$ of cases (Abdelwahab et al. 2018), but lacks specificity; phyllodes tumor and spindle cell metaplastic carcinoma also are immunoreactive for this marker (Lacroix-Triki et al. 2010). Desmin and SMA may be expressed in fibromatosis (Hicks and Lester 2016; Tan and Sahin 2017). By contrast, CD31, CD34, CD99, CD117, BCL2, p63, S100, ER and CKs usually are absent (Bhat et al. 2015; Ashoor et al. 2017; Kuba et al. 2017).

PASH is a benign proliferation of myofibroblastic cells arranged in slit-like pseudovascular spaces lined by spindle shaped myofibroblasts (Virk and Khan 2010). This lesion stains strongly for CD34 (Drinka et al. 2012), although no staining occurs for other endothelial markers including CD31, factors VIII, XIIIa, ERG and von Willebrand (Abdelrahman et al. 2015; Krawczyk et al. 2016; Rosa et al. 2017). CD34 staining can be interpreted as endothelial differentiation, which can be a potential pitfall (Cheah et al. 2016). PASH also can be positive for SMA, BCL2, calponin, CD99, vimentin, actin, PR, ER and desmin (Zámečník 2014; Abdelrahman et al. 2015; Rafeek et al. 2017; Rebutini et al. 2017), although the last two exhibit weak focal staining (Bowman et al. 2012; Rebutini et al. 2017). Reactivity for S100 and CKs is absent (Drinka et al. 2012). Differential diagnoses that can be more doubtful include angiosarcoma and myofibroblastoma. Angiosarcoma can be distinguished using endothelial markers, because staining is observed, by contrast to PASH (Rebutini et al. 2017). In addition, angiosarcoma is unstained for calponin, desmin and actin (Tan and Sahin 2017). Unlike PASH, myofibroblastoma exhibits AR staining (Aytaç et al. 2015).

Myofibroblastoma is a benign myofibroblastic proliferation with a circumscribed border whose cells may exhibit spindle shaped to epithelioid morphology. Cells are arranged in parallel short fascicles interrupted by collagen fibers (Charu and Cimino-Mathews 2017; Tay and Tan 2017). Immunomarkers include CD34, desmin, vimentin, SMA, ER, PR, androgen receptor (AR) and others that can be expressed variably including BCL2, CD99, CD10, calponin and h-caldesmon (Uchoa et al. 2010; Aytaç et al. 2015; Dekate et al. 2015; Metry et al. 2016). Epithelial membrane antigen (EMA) expression occurs occasionally, although it is focal and weak (Howitt and Fletcher 2016). No staining appears for CKs, S100, E-cadherin, human 
melanoma black-45 (HMB-45) and p63 (Dekate et al. 2015; Metry et al. 2016). Myofibroblastoma variants can exhibit a predominance of epithelioid cells and a pseudoinfiltrative pattern, which, in addition to HR staining and absence of E-cadherin staining, can lead to a misdiagnosis of invasive lobular carcinoma (Jing et al. 2017). Differentiation of myofibroblastoma from leiomyoma and low-grade myofibroblastic sarcoma may be necessary. Leiomyoma generally is positive for SMA, desmin and h-caldesmon, but not for CD34, BCL2 and CD99 (Dekate et al. 2015; Kafadar et al. 2017). Absence of CD34 and desmin expression is observed in low grade myofibroblastic sarcoma (Myong and Min 2016).

Phyllodes tumor is a fibroepithelial lesion that exhibits a neoplastic stromal component organized in a leaf-like pattern, and a benign appearing epithelial component. The tumor grade, i.e., benign, borderline or malignant, is based on histologic features including cellularity and atypia of the stroma, tumor border, malignant heterologous elements and mitotic activity (Cheah et al. 2016; Charu and Cimino-Mathews 2017). CD34 and BCL-2 immunostaining is present in the stromal cells of benign and borderline tumors, which helps differentiate it from metaplastic carcinoma (negative expression) (Moore and Lee 2001; CiminoMathews et al. 2014). Malignant tumors tend to be less reactive for $\mathrm{CD} 34$ than benign/borderline tumors; staining was 57 and $100 \%$, respectively (CiminoMathews et al. 2014). In addition to the use of CD34, differentiation of phyllodes tumor from metaplastic carcinoma usually can be accomplished using p63 and a CKs panel owing to the immunostaining of metaplastic carcinoma and the absence of staining in phyllodes tumor; however, malignant tumors occasionally can be positive for both (Cimino-Mathews et al. 2014). Nuclear expression of $\beta$-catenin in $94 \%$ of benign cases and $57 \%$ of borderline/malignant cases has been reported (Lacroix-Triki et al. 2010). Staining for BCL2, ER and PR was reduced in cases of malignancy compared to borderline and benign cases (Moore and Lee 2001; Tse et al. 2002). Esposito et al. (2006) reported an endothelin 1 expression rate of $17 \%$ in malignant cases; $50 \%$ and $100 \%$ were observed for borderline and benign cases, respectively. The expression rates of CD117, Ki-67, CD10, EGFR, IMP3, pH3, p21 and p53 increase progressively according to the degree of malignancy (expression rate: benign cases < borderline cases $<$ malignant cases) (Esposito et al. 2006; Tse et al. 2009; Ibrahim 2011; Korcheva et al. 2011; Noronha et al. 2011; Bellezza et al. 2016).

Spindle cell metaplastic carcinoma must be considered in the differential diagnosis of any spindle cell lesion of the breast. A predominant spindle cell morphology occurs throughout the lesion (Tan and Sahin 2017) and the degree of cytological atypia may range from mild to prominent pleomorphism. Microscopically, spindle cell metaplastic carcinoma typically is infiltrative (Cheah et al. 2016). The spindle cell metaplastic carcinoma pattern may include short or long fascicles arranged in a storiform or herringbone fashion. A mixed pattern also can occur (Charu and Cimino-Mathews 2017). A CK panel generally is applied to assess this condition, because use of single antibodies may produce only focal staining. The most commonly used antibodies include $34 \beta \mathrm{E} 12$, CK5/6, CK14, CK17 (HMWCKs), CK19, CAM5.2 (low molecular weight cytokeratins), AE1/AE3 and MNF116 (pancytokeratins); pan-cytokeratins and HMWCKs are among the most sensitive (Lin et al. 2017; Rakha et al. 2017). Koker et al. (2004) reported p63 staining in $86.7 \%$ of cases; however, malignant phyllodes tumor also can be stained occasionally (Cimino-Mathews et al. 2014). Lacroix-Triki et al. (2010) reported focal nuclear staining for $\beta$-catenin in $23 \%$ of cases. Cimino-Mathews et al. (2013) reported sryrelated HMG-BOX gene 10 (SOX10) protein staining in $46 \%$ of cases, while all phyllodes tumors were negative. Snail was reported to be a sensitive marker for spindle cell metaplastic carcinoma, but exhibited low specificity; staining was observed also for PASH, myofibroblastoma and phyllodes tumor (Nassar et al. 2010). Other markers also can be expressed including S100, EGFR, SMA, vimentin, CD10 and maspin (Altaf et al. 2014; Rakha et al. 2017). ER, PR, human epidermal growth factor receptor 2 (HER2), BCL2 and CD34 usually exhibit no expression (Dunne et al. 2003; Carter et al. 2006; Pezzi et al. 2007; Cimino-Mathews et al. 2014).

\section{Assessment of metastases}

It is crucial to differentiate primary carcinomas from metastases, because different clinical management is involved. Differentiation often can be accomplished by morphology; however, histologic features can be ambiguous. The patient's clinical history and comparison with previous tumor slides may be useful, but these are not always available. IHC can be decisive for assessing the origin of the tumor (Bombonati and Lerwill 2012). Because no single marker is completely specific or sensitive, a panel of antibodies is recommended (Lakhani et al. 2012).

\section{Metastasis to breast}

Extramammary metastases to breast are rare and account for approximately $0.2-2 \%$ of all malignant breast tumors (Peng et al. 2017). In $70-80 \%$ of cases, the history of 
neoplasia in breast is known; however, in the remaining cases, metastasis may be the initial sign of a disseminated neoplasm and it is in this context that IHC can be particularly useful (Lakhani et al. 2012). Because lymph node evaluation and breast surgery generally are not required for metastasis, it is vital to differentiate accurately metastasis from primary breast carcinoma. Lung adenocarcinoma, ovarian and gastric carcinomas, carcinoid tumor, melanoma and prostate carcinoma are among the most common extramammary metastases to breast (Hicks and Lester 2016).

An indication that metastasis may be present is the absence of circumscribed nests of cells and lack of ER, PR and HER2 staining (Zhao et al. 2014), but most of these cases are primary breast carcinomas (Hicks and Lester 2016). Possible immunohistochemical markers used for the cases described above with the respective percentages of staining are presented in Table 2 (Busam and Jungbluth 1999; Filie et al. 2002; Tot 2002; Kidwai et al. 2003; Werling et al. 2003; Chu and Weiss 2004; Dennis et al. 2005; O'Connell et al. 2005; Tornos et al. 2005; Cheng et al. 2006; Fritzsche et al. 2007; Sasaki et al. 2007; Nonaka et al. 2008; Ohsie et al. 2008; Striebel et al. 2008; Wang et al. 2009; Bishop et al. 2010; Gomez-Fernandez et al. 2010; Yang and Nonaka 2010; Shao et al. 2012; Whithaus et al.
2012; Ellis et al. 2013; Miettinen et al. 2014; Hicks and Lester 2016; Ren et al. 2018).

\section{Metastasis from breast}

Although breast metastases may occur in several locations, bone, lung, liver and brain are the most common sites; bone is the most frequent (Hicks and Lester 2016). Common breast specific markers used to evaluate tumors from unknown primary sources include mammaglobin, gross cystic disease fluid protein 15 (GCDFP-15), ER and GATA binding protein 3 (GATA3). Because none of these markers is completely sensitive or specific, it is important to recognize that the clinical context and tumor location, as well as the use of markers specific to other organs, are key factors for interpreting these breast markers and obtaining an accurate diagnosis (Gown et al. 2016).

Different patterns of spread have been observed according to the histological and molecular subtypes. Lobular carcinomas tend to metastasize to peritoneum, retroperitoneum, bone, bone marrow, gynecologic organs and the gastrointestinal tract; ductal carcinomas are more prone to involve lung and pleura (He et al. 2014; Inoue et al. 2017; Mathew et al. 2017). Regarding molecular subtypes, HR-/HER2- profile (basal-like) is associated with

Table 2. Immunohistochemical markers used to differentiate extramammary metastases from primary breast carcinoma with the respective percentages of positivity.

\begin{tabular}{|c|c|c|c|}
\hline & Marker & Extramammary metastases positivity (\%) & Primary breast carcinoma positivity (\%) \\
\hline \multirow[t]{6}{*}{ Lung adenocarcinoma } & Napsin & 83 & 0 \\
\hline & TTF-1 & 60 & 0 \\
\hline & GCDFP-15 & 5 & 62 \\
\hline & Mammaglobin & 0 & 72 \\
\hline & ER & 8 & 81 \\
\hline & GATA3 & 8 & $>90$ \\
\hline \multirow[t]{4}{*}{ Ovarian carcinoma } & WT1 & 76 & 2 \\
\hline & PAX-8 & 87 & 0 \\
\hline & CA 125 & 90 & 16 \\
\hline & GATA3 & 6 & $>90$ \\
\hline \multirow[t]{6}{*}{ Gastric carcinoma } & CK20 & 57 & 5 \\
\hline & $\mathrm{CDX} 2$ & 70 & 0 \\
\hline & GCDFP-15 & 0 & 62 \\
\hline & Mammaglobin & 0 & 72 \\
\hline & GATA3 & 0 & $>90$ \\
\hline & ER & 0 & 81 \\
\hline \multirow[t]{5}{*}{ Carcinoid tumor } & Synaptophysin & 95 & 15 \\
\hline & Chromogranin & 85 & 20 \\
\hline & GCDFP-15 & 5 & 62 \\
\hline & CK7 & 20 & 92 \\
\hline & ER & 10 & 81 \\
\hline \multirow[t]{6}{*}{ Melanoma } & HMB-45 & 81 & 0 \\
\hline & $\mathrm{S} 100$ & 98 & 30 \\
\hline & Melan-A & 81 & 0 \\
\hline & GATA3 & 0 & $>90$ \\
\hline & ER & 0 & 81 \\
\hline & CKs & 4 & $>90$ \\
\hline \multirow[t]{6}{*}{ Prostatic carcinoma } & PSA & 90 & 23 \\
\hline & PAP & 92 & 0 \\
\hline & GCDFP-15 & 10 & 62 \\
\hline & GATA3 & 2 & $>90$ \\
\hline & ER & 11 & 81 \\
\hline & CK7 & 13 & 92 \\
\hline
\end{tabular}

TTF-1,thyroid transcription factor-1; GCDFP-15, gross cystic disease fluid protein 15; ER, estrogen receptor; GATA3, GATA binding protein 3; WT1, Wilm's tumor 1 protein; PAX-8, paired-box gene 8; CA 125, cancer antigen 125; CDX2, homeobox protein CDX2; HMB-45, human melanoma black-45; melan-A, melanoma antigen; PSA, prostate specific antigen; PAP, prostatic acid phosphatase. 
metastases to the brain and lung. Profiles of HR+/HER2(luminal A) and HR+/HER2+ (luminal B) are related to bone metastases. Liver metastases are associated with the HR-/HER2+ profile (HER2-enriched) (Gong et al. 2017; Wu et al. 2017).

\section{Metastasis to axillary sentinel nodes}

Because it is the first to receive lymphatic drainage from a breast tumor, the sentinel lymph node (SLN) is most likely to exhibit metastasis. SLN biopsy is a specific and sensitive way to predict axillary lymph node status and an alternative, with less morbidity, to axillary dissection (Aydiner et al. 2016). Axillary lymph node status is the most significant predictor of diseasefree survival and represents an integral component of the staging and treatment of breast cancer (Liu et al. 2017; Nicolini et al. 2017).

Despite several proposals, a standardized protocol for histopathological evaluation of SLN remains elusive (Charalampoudis and Markopoulos 2018). Intraoperative frozen sections currently are the accepted standard; however, these can be false negative in $>25 \%$ of cases. Therefore, generally accepted practice requires at least three $\mathrm{H} \& \mathrm{E}$ stained sections, which should detect most metastases, and a minimum of one IHC section for pancytokeratins (Van et al. 2016). IHC can be helpful for assessing a suspicious area in an $\mathrm{H} \& \mathrm{E}$ section, particularly for detecting micrometastases and isolated tumor cells (ITC). IHC can detect positivity in $12-29 \%$ of SLN sections that were missed by $\mathrm{H} \& \mathrm{E}$; these are mostly micrometastases and ITC (Apple 2016). In addition to the use of $\mathrm{IHC}$, the greater the number of sections obtained from a block and stained with $\mathrm{H} \& \mathrm{E}$, the greater the chance of detecting metastases (Giobuin et al. 2011). The significance of micrometastases and ITC, however, is uncertain (Youssef et al. 2016).

\section{Prognostic and predictive factors}

Prognostic factors provide necessary information concerning the patient's probable clinical course, indicate disease-free or overall survival and suggest the biological aggressiveness of a tumor (Aydiner et al. 2016). Evaluation of predictive factors enables estimation of whether a patient will benefit from or be resistant to a certain treatment, as well as selection of specific treatments for each case, which improves the response rate and reduces toxicity owing to nonbeneficial therapies (Hicks and Lester 2016; Nicolini et al. 2017). Some factors, such as ER, PR and HER2 status, can be both prognostic and predictive (Shousha 2017).

Morphologic factors for prognosis include lymph node status, the most significant predictor of disease-free survival; poorer prognosis with each additional lymph node involved (Schwartz et al. 2014; Van et al. 2016), tumor size with direct correlation between the number of involved lymph nodes and risk of recurrence (Foulkes et al. 2010; Shahriari-Ahmadi et al. 2017), tumor histologic type and grade; well differentiated and poorly differentiated tumors exhibit favorable or less favorable prognosis, respectively (Eliyatkin et al. 2015), distant metastases, presence of lymph-vascular invasion, proliferative rate, ER, PR and HER2 status (Aydiner et al. 2016).

Patient characteristics including age, co-morbidities and menopausal status also should be considered. In addition, a combination of factors have more prognostic value than each factor individually (Hicks and Lester 2016).

Although the advances that have been made in molecular classification of breast cancer, e.g., gene expression profiling, their clinical applicability remains limited; pathologists continue to use conventional techniques such as IHC and in situ hybridization (ISH) (Rakha and Green 2017).

\section{Hormone receptors}

ER and PR evaluation is essential for all newly diagnosed cases of breast cancer, and when applicable, for recurrent/metastatic ones (Nicolini et al. 2017). Positive ER and PR expression is associated with longer disease-free status and overall survival and is an indicator of responsiveness to endocrine therapy (Ly et al. 2012; Honma et al. 2014).

$\mathrm{HR}$ can be informative for prognosis: it may predict a slow growing indolent tumor with later recurrence (Aydiner et al. 2016). HR are used mainly to predict endocrine therapy response, however, and particularly to identify patients with early breast cancer who might benefit from such treatments. Endocrine therapy should be considered for patients with ER-positive tumors; conversely, it is not applicable for patients with ERnegative tumors (Nicolini et al. 2017). Nevertheless, negative HR cases exhibited a better response to chemotherapy compared to positive HR cases (Early Breast Cancer Trialists' Collaborative Group 2005).

HR typically is assessed by IHC. If $\geq 1 \%$ of the tumor cell nuclei are reactive, the tumor can be considered positive and endocrine therapy may be considered (Zaha 2014). It also is important to consider staining intensity (weak, moderate, strong) in the tumor in addition to the percentage of stained cells (Hammond et al. 2010; Brouckaert et al. 2012).

\section{HER2}

HER2 overexpression, which plays an important role in sustaining several pathways for tumor growth, occurs in 
$15-30 \%$ of breast cancers and is associated with poor prognosis (Iqbal and Iqbal 2014). HER2 is associated with frequent lymph node metastases, high grade histopathology and high mitotic activity (Ly et al. 2012). Beyond its use for prognosis, HER2 overexpression is used to identify patients who may benefit from HER2-targeted therapies, such as trastuzumab, and to predict response to anthracyclinebased chemotherapies (Gennari et al. 2008; Slamon et al. 2011). HER2-targeted therapies are applicable only in patients with HER2 overexpression in adjuvant, neoadjuvant and metastatic contexts (Slamon et al. 2001; Mass et al. 2005; Seidman et al. 2008). Similarly, anthracycline based chemotherapies are related to better outcomes in HER2-positive patients (Gennari et al. 2008). HER2 overexpression may be an indicator of resistance and lower response rates to endocrine therapies: despite some conflicting reports, an unfavorable impact on response to tamoxifen has been reported (Wright et al. 1992; Leitzel et al. 1995; Yamauchi et al. 1997; Elledge et al. 1998; Lipton et al. 2003).

IHC, fluorescence in situ hybridization (FISH) and chromogenic in situ hybridization (CISH) are among the techniques available for assessing HER2 status (Rosa et al. 2013). IHC has been widely used despite the greater precision and reproducibility with the FISH technique. IHC is a rapid assay and is less demanding technically (Press et al. 2002; Penault-Llorca et al. 2009). HercepTest ${ }^{\mathrm{TM}}$ classifications based on HER2 IHC staining are described in Table 3 (Dako 2014). Weakly positive cases require confirmation and should be retested using ISH (Dako 2014; Zaha 2014).

\section{Proliferation assessment}

Proliferation can be used to evaluate prognosis and treatment. In addition to mitotic index assessment using $\mathrm{H}$ \& E staining, IHC, ISH, flow cytometry or gene expression profiling can be used (Badve and GökmenPolar 2016). IHC can be used to evaluate markers including Ki-67, p21, p27, cyclin-D and cyclin-E (Fayed et al. 2012; Gao et al. 2013; Xu et al. 2013; Soliman and Anis 2014).

Table 3. Classifications and immunohistochemical reactions of HER2 HercepTest ${ }^{T M}$ assay (Dako 2014).

\begin{tabular}{|c|c|c|}
\hline Score & $\begin{array}{c}\text { HER2 } \\
\text { classification }\end{array}$ & Staining pattern \\
\hline $3+$ & Positive & $\begin{array}{l}\text { Strong complete membrane staining in }>10 \% \text { of } \\
\text { tumor cells }\end{array}$ \\
\hline $2+$ & $\begin{array}{l}\text { Weakly } \\
\text { positive }\end{array}$ & $\begin{array}{l}\text { Weak to moderate complete membrane staining } \\
\text { in }>10 \% \text { of tumor cells }\end{array}$ \\
\hline $1+$ & Negative & $\begin{array}{l}\text { Faint/barely perceptible, incomplete, membrane } \\
\text { staining in }>10 \% \text { of tumor cells }\end{array}$ \\
\hline $0+$ & Negative & $\begin{array}{l}\text { Absence of staining, or membrane staining in }< \\
10 \% \text { of tumor cells }\end{array}$ \\
\hline
\end{tabular}

Ki-67, despite disadvantages including lack of standardization and poor reproducibility, is a widely used immunomarker for assessing proliferation; it is affordable and technically less demanding than gene expression profiling (Shousha 2017). The percentage of stained cells (nuclear staining) among the total number of tumor cells in the evaluated area, gives the Ki-67 index. This is used mainly to differentiate luminal A from luminal B subtypes, which may guide therapeutic management. Low proliferation is associated with the luminal A subtype, whereas the luminal B subtype is associated with higher proliferation rates (Shousha 2017). Over the years, the St. Gallen Panel has proposed criteria to define standard values: $\leq 15 \%, 16-30 \%$ and $>30 \%$ for low, intermediate and high rates, respectively, and cut points of Ki67 positive tumor cells of $14 \%, 20 \%$ and $30 \%$ to differentiate luminal A from luminal B subtypes. The Panel noted a high degree of inter-laboratory variation in Ki-67 measurement, therefore the cut points should be interpreted with consideration for local laboratory values (Goldhirsch et al. 2009, 2011, 2013; Coates et al. 2015).

Highly proliferative tumors are associated with poor prognosis, but are more likely to respond to chemotherapy (Kim et al. 2014). For low proliferating tumors, despite the lack of response to chemotherapy, low Ki-67 rates are associated with good prognosis. In highly proliferative tumors that are sensitive to therapy, high $\mathrm{Ki}-67$ rates are associated with a favorable outcome, i.e., improved survival and improved chances of complete response (absence of cancerous cells in the tissue samples removed during biopsy or surgery after chemotherapy or radiation). For highly proliferative tumors that are resistant to chemotherapy, high expression of Ki-67 is associated with reduced survival and unfavorable outcome (Denkert et al. 2015).

\section{Lymph-vascular invasion}

Lymph-vascular invasion (LVI) is the first step in the spread of tumor cells; these cells can remain in the breast to form secondary invasive foci or leave through the blood or lymph vessels (Tot et al. 2014). LVI can be defined as the presence of a tumor embolus within an endothelium-lined space in the peritumor area (Agarwal et al. 2018). LVI detection is particularly valuable for node-negative patients and can be used to make decisions regarding adjuvant therapy (Shousha 2017). Several factors exhibit an increased risk of occurrence due to LVI: axillary lymph node metastases, local/distant recurrence independent of the axillary node status and metastases in additional nodes in positive sentinel node cases. Also, LVI can be associated with resistance to chemotherapy as well as with other aggressive features 
including lack of HR expression, high histologic grade and high Ki-67 rate (Hicks and Lester 2016).

IHC can be used to detect LVI; IHC increases the frequency of detection compared to $\mathrm{H} \& \mathrm{E}$ staining. Both methods have prognostic significance (Mohammed et al. 2007). ERG, CD31, CD34, factor VIII and podoplanin are commonly used immunomarkers (Kim et al. 2013; Gujam et al. 2014; Agarwal et al. 2018). ERG, which is specific for endothelial cells, exhibits nuclear immunoreactivity in blood and lymphatic vessels. CD31 expression appears in blood vessels and is variably present in lymphatic vessels. CD34 staining occurs in blood vessels and weakly in lymphatic vessels; also, stromal cells are positive, which reduces its usefulness for distinguishing LVI from retraction artifacts. Factor VIII is expressed in both blood and lymphatic vessels; it is weaker in small vessels. Podoplanin staining is observed in lymphatic vessels, but not in blood vessels; it also is positive in MECs, so it is of little value for differentiating LVI from DCIS. It is not necessary to distinguish blood and lymphatic vessels, because both have prognostic significance (Aydiner et al. 2016; Hicks and Lester 2016; Shousha 2017).

Retraction artifacts mimic true LVI. DCIS, as LVI, form circumscribed nests of tumor cells. Retraction artifacts and DCIS are the main conditions that may resemble LVI and lead to misdiagnosis. The MEC layer can differentiate LVI from DCIS. The MEC layer can be assessed using the p63 immunomarker (Koo et al. 2010). SMMHC stains smooth muscle in the walls of blood vessels, so it should not be used to differentiate LVI from DCIS (Shousha 2017). To identify retraction artifacts, vascular markers such as podoplanin or CD31, can be used to highlight LVI (Dileep and Prasad 2018).

\section{Molecular subtypes}

Classification of tumors into molecular subtypes according to their gene expression profiles is important for prognosis and for choosing specific treatments. Classification can be done using the IHC markers, ER, PR, HER2, Ki-67, EGFR and basal CKs. The four major subtypes are luminal $A$, luminal B, HER2-enriched and basal-like (Eliyatkin et al. 2015).

Luminal A comprises $50-60 \%$ of breast cancers, whose profile is defined by positive ER, usually positive $P R$, negative HER2, low Ki-67 proliferation and low to absent basal CKs or EGFR. Prognosis is favorable; it is responsive to endocrine therapy and variably responsive to chemotherapy. Time to recurrence can be > 10 years (Yersal and Barutca 2014; Eliyatkin et al. 2015; Hicks and Lester 2016).

Fifteen to twenty percent of breast cancers have a luminal B profile, which is defined by positive ER, negative to low $\mathrm{PR}$, variable HER2 expression, higher Ki67 proliferation than luminal A and low to absent basal CKs or EGFR. Prognosis is less favorable than luminal A. HER2targeted therapy can be used for HER2 positive cases. Luminal B profile is less responsive to endocrine therapy than luminal $A$ and exhibits a variable, but better than luminal A, response to chemotherapy. Time to recurrence is $<10$ years (Yersal and Barutca 2014; Eliyatkin et al. 2015; Badve and Gökmen-Polar 2016; Hicks and Lester 2016).

HER2-enriched subtypes represent $15-20 \%$ of breast cancers, whose profile is defined by negative ER, negative $\mathrm{PR}$, positive HER2, high Ki-67 and possible presence of basal CKs or EGFR. Prognosis usually is unfavorable. This cancer is responsive to HER2-targeted therapy and to chemotherapy with anthracyclines. Time to recurrence is $<10$ years (Yersal and Barutca 2014; Eliyatkin et al. 2015; Hicks and Lester 2016).

Ten to fifteen percent of breast cancers have a basal-like profile, which is defined by negative ER, PR and HER2 (triple negative), high Ki-67 proliferation and presence of basal CKs and EGFR. The prognosis is unfavorable; this cancer is responsive to endocrine or HER2-targeted therapies, and platinum group chemotherapies and PARP inhibitors can be beneficial. Because EGFR frequently is overexpressed, it also may be a potential therapeutic target. Time to recurrence is < 5 years (Yersal and Barutca 2014; Eliyatkin et al. 2015; Hicks and Lester 2016). Owing to the need to improve therapeutic outcomes and because of their immunogenic characteristics, the programmed deathligand 1 (PD-L1) is a potential target for triple negative breast cancers. This ligand was overexpressed in approximately $20 \%$ of triple negative breast cancers, which suggests a potential role for anti-PD-L1 therapy (Mittendorf et al. 2014). Phase I clinical trials using antiPD-L1 antibodies exhibited tumor size reduction and a positive reaction to therapy (Pusztai et al. 2016).

\section{Conclusions}

Although most diagnoses of breast pathologies can be accomplished using $\mathrm{H}$ \& $\mathrm{E}$ stained sections, several types cause diagnostic problems for which IHC becomes a vital tool (Table 4). Owing to the complex nature of mammary lesions, the success of diagnosis also depends on understanding each particular situation. To avoid incorrect interpretation of immunostaining, it is mandatory to evaluate the cytological characteristics carefully and to correlate the histological findings. IHC plays a vital role for prognosis and predicting response to therapy. Despite advances in the molecular classification of breast cancer, conventional techniques, such as IHC, remain indispensable to everyday clinical practice. 
Table 4. Immunomarkers for breast cancer for assessing various conditions, respective location/marking pattern, and positivity and negativity.

\begin{tabular}{|c|c|c|c|c|}
\hline Marker & Staining pattern & Positive & Negative & References \\
\hline $34 \beta E 12$ & $\begin{array}{l}\text { Perinuclear cytoplasmic } \\
\text { Cytoplasmic }\end{array}$ & $\begin{array}{l}\text { Lobular carcinoma } \\
\text { UDH }\end{array}$ & $\begin{array}{l}\text { Ductal carcinoma } \\
\mathrm{ADH} \text { and DCIS }\end{array}$ & $\begin{array}{l}\text { Bratthauer et al. 2002 } \\
\text { Moinfar et al. 1999; Lacroix-Triki et al. } 2003\end{array}$ \\
\hline Actin & Spindle cells & PASH & Angiosarcoma & Rosa et al. 2017; Tan and Sahin 2017 \\
\hline & Spindle cells & Myofibroblastoma & PASH & Ibrahim and Shousha 2013; Aytaç et al. 2015 \\
\hline \multirow[t]{4}{*}{$\beta$-catenin } & $\begin{array}{l}\text { Membranous with/without cytoplasmic expression } \\
\text { Membranous negative/cytoplasmic granular }\end{array}$ & $\begin{array}{l}\text { Ductal carcinoma } \\
\text { Lobular carcinoma }\end{array}$ & & Dabbs et al. 2007a; Karabacak et al. 2011 \\
\hline & Nuclear & Fibromatosis & & Abdelwahab et al. 2018 \\
\hline & Nuclear in stromal cells & $\begin{array}{l}\text { More expressed in benign phyllodes tumor than } \\
\text { borderline/malignant }\end{array}$ & & Lacroix-Triki et al. 2010 \\
\hline & Nuclear & $\begin{array}{l}\text { Occasionally expressed in spindle cell metaplastic } \\
\text { carcinoma }\end{array}$ & & Lacroix-Triki et al. 2010 \\
\hline \multirow[t]{5}{*}{ BCL2 } & & Usually negative in fibromatosis & & Ashoor et al. 2017 \\
\hline & Spindle cells & PASH & & Charu and Cimino-Mathews 2017 \\
\hline & & Variably expressed in myofibroblastoma & Leiomyoma & Dekate et al. 2015; Magro 2017 \\
\hline & Stromal cells & Benign and borderline phyllodes tumors & $\begin{array}{l}\text { Spindle cell metaplastic } \\
\text { carcinoma }\end{array}$ & Moore and Lee 2001; Cimino-Mathews et al. 2014 \\
\hline & $\begin{array}{l}\text { Lower expression in malignant phyllodes tumor than } \\
\text { benign/borderline }\end{array}$ & & & Moore and Lee 2001 \\
\hline CA 125 & $\begin{array}{l}\text { Used to distinguish metastatic ovarian carcinoma from } \\
\text { primary breast carcinoma }\end{array}$ & & & Tornos et al. 2005 \\
\hline \multirow{2}{*}{ Calponin } & Cytoplasmic & In situ carcinoma & Invasive carcinoma & Yeh I-T 2008 \\
\hline & Spindle cells & $\begin{array}{l}\text { PASH } \\
\text { Variably expressed in myofibroblastoma }\end{array}$ & Angiosarcoma & $\begin{array}{l}\text { Lakhani et al. 2012; Tan and Sahin } 2017 \\
\text { Magro } 2017\end{array}$ \\
\hline \multirow{3}{*}{ CD10 } & Spindle cells & Variably expressed in myofibroblastoma & & Magro 2017 \\
\hline & & Spindle cell metaplastic carcinoma & & Rakha et al. 2017 \\
\hline & $\begin{array}{l}\text { Proportional association between expression and degree in } \\
\text { phyllodes tumor }\end{array}$ & & & Ibrahim 2011 \\
\hline \multirow{2}{*}{ CD117 } & & Usually negative in fibromatosis & & Bhat et al. 2015 \\
\hline & $\begin{array}{l}\text { Proportional association between expression and degree in } \\
\text { phyllodes tumor }\end{array}$ & & & Noronha et al. 2011 \\
\hline \multirow[t]{3}{*}{ CD31 } & & Usually negative in fibromatosis & & Charu and Cimino-Mathews 2017 \\
\hline & Spindle cells & Angiosarcoma & PASH & Rebutini et al. 2017; Rosa et al. 2017 \\
\hline & Expressed in BV and variably in LV & Used to evaluate lymph-vascular invasion & Retraction artifacts & $\begin{array}{l}\text { Gujam et al. 2014; Shousha } 2017 \\
\text { Dileep and Prasad } 2018\end{array}$ \\
\hline \multirow{5}{*}{ CD34 } & & Usually negative in fibromatosis & Ketradtion drtilacts & Tan and Sahin 2017 \\
\hline & Spindle cells & PASH & & Virk and Khan 2010 \\
\hline & & Myofibroblastoma & $\begin{array}{l}\text { Leiomyoma and } \\
\text { low-grade myofibroblastic } \\
\text { sarcoma }\end{array}$ & $\begin{array}{l}\text { Metry et al. 2016; Myong and Min 2016; Magro } \\
2017\end{array}$ \\
\hline & Stromal cells & $\begin{array}{l}\text { Benign and borderline phyllodes tumors } \\
\text { malignant less reactive }\end{array}$ & $\begin{array}{l}\text { Spindle cell metaplastic } \\
\text { carcinoma }\end{array}$ & Moore and Lee 2001; Cimino-Mathews et al. 2014 \\
\hline & $\begin{array}{l}\text { BV and more weakly in } \\
\text { LV }\end{array}$ & Used to evaluate lymph-vascular invasion & & Shousha 2017; Agarwal et al. 2018 \\
\hline \multirow[t]{3}{*}{ CD99 } & & Usually negative in fibromatosis & & Ashoor et al. 2017 \\
\hline & Spindle cells & PASH & & Charu and Cimino-Mathews 2017 \\
\hline & & Variably expressed in myofibroblastoma & Leiomyoma & Dekate et al. 2015; Magro 2017 \\
\hline CDX2 & $\begin{array}{l}\text { Used to distinguish metastatic gastric carcinoma from } \\
\text { primary breast carcinoma }\end{array}$ & & & Werling et al. 2003 \\
\hline Chromogranin & $\begin{array}{l}\text { Cytoplasmic } \\
\text { Used to distinguish metastatic carcinoid tumor from } \\
\text { primary breast carcinoma }\end{array}$ & SPC & & $\begin{array}{l}\text { Otsuki et al. } 2007 \\
\text { Hicks and Lester } 2016\end{array}$ \\
\hline
\end{tabular}


Table 4. (Continued).

\begin{tabular}{|c|c|c|c|c|}
\hline Marker & Staining pattern & Positive & Negative & References \\
\hline CK 5/6 & $\begin{array}{l}\text { Cytoplasmic } \\
\text { Cytoplasmic }\end{array}$ & $\begin{array}{l}\text { UDH } \\
\text { IDP with UDH }\end{array}$ & $\begin{array}{l}\text { ADH and DCIS } \\
\text { Atypical papilloma } \\
\text { IDP with DCIS } \\
\text { EPC and SPC }\end{array}$ & $\begin{array}{l}\text { Otterbach et al. 2000; Lacroix-Triki et al. } 2003 \\
\text { Nofech-mozes et al. } 2008 \\
\text { Jorns } 2016 \\
\text { Rabban et al. 2006; Agoumi et al. } 2016\end{array}$ \\
\hline \multirow[t]{5}{*}{ CKs } & & Usually negative in fibromatosis & & Tan and Sahin 2017 \\
\hline & & & $\begin{array}{l}\text { PASH } \\
\text { Mvofibroblastoma }\end{array}$ & Charu and Cimino-Mathews 2017 \\
\hline & Spindle cells & Spindle cell metaplastic carcinoma & $\begin{array}{l}\text { Phyllodes tumor malignant } \\
\text { may be positive }\end{array}$ & Cimino-Mathews et al. 2014 \\
\hline & Used to assess breast origin & & & Shao et al. 2012 \\
\hline & Used to assess metastasis in axillary sentinel nodes & & & Apple 2016; Van et al. 2016 \\
\hline CK20 & $\begin{array}{l}\text { Used to distinguish metastatic gastric carcinoma from } \\
\text { primary breast carcinoma }\end{array}$ & & & Chu and Weiss 2004 \\
\hline CK7 & Used to assess breast origin & & & Bombonati and Lerwill 2012 \\
\hline CK8 & $\begin{array}{l}\text { Peripheralpredominant cytoplasmic } \\
\text { Perinuclear }\end{array}$ & $\begin{array}{l}\text { Ductal carcinoma } \\
\text { Lobular carcinoma }\end{array}$ & & Lehr et al. 2000 \\
\hline $\begin{array}{l}\text { Cyclin-D and } \\
\text { Cyclin-E }\end{array}$ & Can be used to evaluate proliferation & & & Gao et al. 2013; Xu et al. 2013 \\
\hline \multirow[t]{2}{*}{ Desmin } & Cytoplasmic & May be expressed in fibromatosis & & Tan and Sahin 2017 \\
\hline & Spindle cells & $\begin{array}{l}\text { Variable positive in PASH } \\
\text { Myofibroblastoma }\end{array}$ & $\begin{array}{l}\text { Angiosarcoma } \\
\text { Low-grade myofibroblastic } \\
\text { sarcoma }\end{array}$ & $\begin{array}{l}\text { Lakhani et al. 2012; Tan and Sahin } 2017 \\
\text { Metry et al. 2016; Myong and Min } 2016\end{array}$ \\
\hline E-cadherin & Membranous & Ductal carcinoma & $\begin{array}{l}\text { Lobular carcinoma } \\
\text { Myofibroblastoma }\end{array}$ & $\begin{array}{l}\text { Li et al. } 2014 \\
\text { Dekate et al. } 2015\end{array}$ \\
\hline \multirow[t]{3}{*}{ EGFR } & $\begin{array}{l}\text { Proportional association between expression and degree in } \\
\text { phyllodes tumor }\end{array}$ & & & Tse et al. 2009 \\
\hline & Spindle cells & Spindle cell metaplastic carcinoma & & Rakha et al. 2017 \\
\hline & Used as a prognosis factor & & & Hicks and Lester 2016 \\
\hline EMA & Focal and weak in spindle cells & Occasionally expressed in myofibroblastoma & & Howitt and Fletcher 2016 \\
\hline $\begin{array}{l}\text { Endothelial } \\
\text { markers }\end{array}$ & Spindle cells & Angiosarcoma & $\begin{array}{l}\text { PASH } \\
\text { although positive for CD34 }\end{array}$ & Rafeek et al. 2017; Rebutini et al. 2017 \\
\hline Endothelin 1 & Negativity related to malignant phyllodes tumor & & & Esposito et al. 2006 \\
\hline \multirow{10}{*}{ ER } & Nuclear scattered & UDH & & Lin et al. 2015 \\
\hline & Nuclear diffuse & $\mathrm{ADH}$ and $\mathrm{DCIS}$ & & \\
\hline & Strong diffuse & Atypical papilloma & IDP with UDH & Grin et al. 2009 \\
\hline & Diffuse & IDP with DCIS & & Jorns 2016 \\
\hline & Diffuse & EPC & & Agoumi et al. 2016 \\
\hline & & Usually negative in fibromatosis & & Charu and Cimino-Mathews 2017 \\
\hline & $\begin{array}{l}\text { Focal and weak } \\
\text { Spindle cells }\end{array}$ & $\begin{array}{l}\text { PASH } \\
\text { Myofibroblastoma }\end{array}$ & $\begin{array}{l}\text { Spindle cell metaplastic } \\
\text { carcinoma }\end{array}$ & $\begin{array}{l}\text { Carter et al. 2006; Virk and Khan 2010; Aytaç et al. } \\
2015\end{array}$ \\
\hline & $\begin{array}{l}\text { Lower expression in malignant phyllodes tumor than } \\
\text { benign/borderline }\end{array}$ & & & Tse et al. 2002 \\
\hline & Used to assess breast origin & & & Gown et al. 2016 \\
\hline & Used as a prognosis factor & & & Shousha 2017 \\
\hline & Nuclear in BV and LV & Used to evaluate lymph-vascular invasion & & Kim et al. 2013 \\
\hline \multirow[t]{2}{*}{ Factor VIII } & BV and LV & Used to evaluate lymph-vascular invasion & & Gujam et al. 2014; Shousha 2017 \\
\hline & & & PASH & Rafeek et al. 2017 \\
\hline GATA3 & Used to assess breast origin & & & Gown et al. 2016 \\
\hline GCDFP-15 & Cytoplasmic & Apocrine carcinoma & & Darb-Esfahani et al. 2014 \\
\hline H-caldesmon & $\begin{array}{l}\text { Used to assess breast origin } \\
\text { Spindle cells }\end{array}$ & Variably expressed in myofibroblastoma & & $\begin{array}{l}\text { Gown et al. } 2016 \\
\text { Metry et al. } 2016\end{array}$ \\
\hline
\end{tabular}


Table 4. (Continued).

\begin{tabular}{|c|c|c|c|c|}
\hline Marker & Staining pattern & Positive & Negative & References \\
\hline HER2 & & & $\begin{array}{l}\text { Spindle cell metaplastic } \\
\text { carcinoma }\end{array}$ & Carter et al. 2006 \\
\hline & Used as a prognosis factor & & & Shousha 2017 \\
\hline \multirow{2}{*}{ HMB-45 } & & & Myofibroblastoma & Metry et al. 2016 \\
\hline & $\begin{array}{l}\text { Used to distinguish metastatic melanoma from primary } \\
\text { breast carcinoma }\end{array}$ & & & Filie et al. 2002 \\
\hline IMP3 & $\begin{array}{l}\text { Proportional association between expression and degree in } \\
\text { phyllodes tumor }\end{array}$ & & & Bellezza et al. 2016 \\
\hline \multirow[t]{2}{*}{ Ki-67 } & $\begin{array}{l}\text { Proportional association between expression and degree in } \\
\text { phyllodes tumor }\end{array}$ & & & Noronha et al. 2011 \\
\hline & Used to evaluate proliferation & & & Shousha 2017 \\
\hline Mammaglobin & Used to assess breast origin & & & Gown et al. 2016 \\
\hline Maspin & Spindle cells & Spindle cell metaplastic carcinoma & & Rakha et al. 2017 \\
\hline \multirow[t]{6}{*}{ MEC markers } & MEC & In situ carcinoma & Invasive carcinoma & Yeh I-T 2008 \\
\hline & $\begin{array}{l}\text { Within the papillae and peripheral } \\
\text { Peripheral only }\end{array}$ & $\begin{array}{l}\text { IDP with DCIS } \\
\text { Papillary DCIS }\end{array}$ & EPC and SPC & Tse et al. 2007; Jorns 2016 \\
\hline & MEC & IDP with abundant sclerosis & Invasion & Mugler et al. 2007 \\
\hline & & 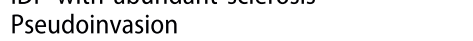 & Papillary DCIS invasion & Tse et al. 2007 \\
\hline & & & & Hicks and Lester 2016 \\
\hline & & Sclerosing adenosis and radial scars & Invasive carcinoma & Liu 2014; Zaha 2014 \\
\hline Melan-A & $\begin{array}{l}\text { Used to distinguish metastatic melanoma from primary } \\
\text { breast carcinoma }\end{array}$ & & & Busam and Jungbluth 1999 \\
\hline Napsin & $\begin{array}{l}\text { Used to distinguish metastatic lung adenocarcinoma from } \\
\text { primary breast carcinoma }\end{array}$ & & & Bishop et al. 2010 \\
\hline p120 catenin & $\begin{array}{l}\text { Membranous } \\
\text { Cytoplasmic }\end{array}$ & $\begin{array}{l}\text { Ductal carcinoma } \\
\text { Lobular carcinoma }\end{array}$ & & Dabbs et al. 2007a, 2007b; Li et al. 2014 \\
\hline \multirow[t]{2}{*}{ p21 } & $\begin{array}{l}\text { Proportional association between expression and degree in } \\
\text { phyllodes tumor }\end{array}$ & & & Esposito et al. 2006 \\
\hline & Can be used to evaluate proliferation & & & Soliman and Anis 2014 \\
\hline p27 & Can be used to evaluate proliferation & & & Fayed et al. 2012 \\
\hline p53 & $\begin{array}{l}\text { Proportional association between expression and degree in } \\
\text { phyllodes tumor }\end{array}$ & & & Korcheva et al. 2011 \\
\hline \multirow[t]{3}{*}{ p63 } & Nuclear & In situ carcinoma & Invasive carcinoma & $\begin{array}{l}\text { Yeh I-T } 2008 \\
\text { Rakha et al } 2016\end{array}$ \\
\hline & & Usually negative in fibromatosis & Myofibroblastoma & Charu and Cimino-Mathews 2017 \\
\hline & Nuclear & Spindle cell metaplastic carcinoma & $\begin{array}{l}\text { Phyllodes tumor malignant } \\
\text { may be positive }\end{array}$ & Koker et al. 2004; Cimino-Mathews et al. 2014 \\
\hline $\begin{array}{l}\text { p75 neurotrophin } \\
\text { receptor }\end{array}$ & Membranous and cytoplasmic & In situ carcinoma & Invasive carcinoma & Popnikolov et al. 2005 \\
\hline PAP & $\begin{array}{l}\text { Used to distinguish metastatic prostatic carcinoma from } \\
\text { primary breast carcinoma }\end{array}$ & & & Cheng et al. 2006 \\
\hline PAX8 & $\begin{array}{l}\text { Used to distinguish metastatic ovarian carcinoma from } \\
\text { primary breast carcinoma }\end{array}$ & & & Nonaka et al. 2008 \\
\hline $\mathrm{pH} 3$ & $\begin{array}{l}\text { Proportional association between expression and degree in } \\
\text { phyllodes tumor }\end{array}$ & & & Korcheva et al. 2011 \\
\hline Podoplanin & LV & Used to evaluate lymph-vascular invasion & & Shousha 2017; Agarwal et al. 2018 \\
\hline \multirow[t]{4}{*}{ PR } & Nuclear in stromal cells & $\begin{array}{l}\text { LVI } \\
\text { PASH }\end{array}$ & $\begin{array}{l}\text { Retraction artifacts } \\
\text { Spindle cell metaplastic }\end{array}$ & $\begin{array}{l}\text { Dileep and Prasad } 2018 \\
\text { Virk and Khan 2010; Cimino-Mathews et al. 2014; }\end{array}$ \\
\hline & $\begin{array}{l}\text { Spindle cells } \\
\text { Stits }\end{array}$ & Myofibroblastoma & carcinoma & Metry et al. 2016 \\
\hline & $\begin{array}{l}\text { Lower expression in malignant phyllodes tumor than } \\
\text { benign/borderline }\end{array}$ & & & Tse et al. 2002 \\
\hline & Used as a prognosis factor & & & Shousha 2017 \\
\hline
\end{tabular}


Table 4. (Continued).

\begin{tabular}{|c|c|c|c|c|}
\hline Marker & Staining pattern & Positive & Negative & References \\
\hline PSA & $\begin{array}{l}\text { Used to distinguish metastatic prostatic carcinoma from } \\
\text { primary breast carcinoma }\end{array}$ & & & Hicks and Lester 2016 \\
\hline \multirow[t]{3}{*}{ S100 } & & Usually negative in fibromatoses & & Tan and Sahin 2017 \\
\hline & Spindle cells & Spindle cell metaplastic carcinoma & $\begin{array}{l}\text { PASH } \\
\text { Myofibroblastoma }\end{array}$ & $\begin{array}{l}\text { Cheah et al. 2016; Metry et al. 2016; Charu and } \\
\text { Cimino-Mathews } 2017\end{array}$ \\
\hline & $\begin{array}{l}\text { Used to distinguish metastatic melanoma from primary } \\
\text { breast carcinoma }\end{array}$ & & & Ren et al. 2018 \\
\hline \multirow[t]{3}{*}{ SMA } & Cytoplasmic & May be expressed in fibromatosis & & Tan and Sahin 2017 \\
\hline & Spindle cells & PASH & & Virk and Khan 2010 \\
\hline & & Myofibroblastoma & & Metry et al. 2016 \\
\hline SMMHC & Cytoplasmic & In situ carcinoma & Jnencing sarcinom & Rakha et al. 2017 \\
\hline $\begin{array}{l}\text { SMMMHC } \\
\text { Snail }\end{array}$ & $\begin{array}{l}\text { Cytoplasmic } \\
\text { Sensitive for spindle cell metaplastic carcinoma but } \\
\text { reduced specificity }\end{array}$ & In situ carcinoma & Invasive carcinoma & $\begin{array}{l}\text { Yeh I-I } 2008 \\
\text { Nassar et al. } 2010\end{array}$ \\
\hline SoX10 & Spindle cells & $\begin{array}{l}\text { Variably expressed in spindle cell metaplastic } \\
\text { carcinoma }\end{array}$ & Phyllodes tumors & Cimino-Mathews et al. 2013 \\
\hline Synaptophysin & $\begin{array}{l}\text { Cytoplasmic } \\
\text { Used to distinguish metastatic carcinoid tumor from } \\
\text { primary breast carcinoma }\end{array}$ & SPC & & $\begin{array}{l}\text { Otsuki et al. } 2007 \\
\text { Hicks and Lester } 2016\end{array}$ \\
\hline TFF-1 & $\begin{array}{l}\text { Used to distinguish metastatic lung adenocarcinoma from } \\
\text { primary breast carcinoma }\end{array}$ & & & Whithaus et al. 2012 \\
\hline \multirow[t]{2}{*}{ Vimentin } & Spindle cells & $\begin{array}{l}\text { PASH } \\
\text { Myofibroblastoma }\end{array}$ & & $\begin{array}{l}\text { Virk and Khan } 2010 \\
\text { Magro } 2017\end{array}$ \\
\hline & & Spindle cell metaplastic carcinoma & - & Altaf et al. 2014 \\
\hline WT1 & $\begin{array}{l}\text { Used to distinguish metastatic ovarian carcinoma from } \\
\text { primary breast carcinoma }\end{array}$ & & & Tornos et al. 2005 \\
\hline $\begin{array}{l}\text { UDH, usual dc } \\
\text { antigen } 125 \\
\text { carcinoma; } \\
\text { growth fact } \\
\text { paired-box }\end{array}$ & $\begin{array}{l}\text { rplasia; ADH, atypical ductal hyperplasia; DCIS, ductal car } \\
\text { h-vascular invasion; BV, blood vessels; LV, lymphatic vesse } \\
\text { dermal growth factor receptor; EMA, epithelial membrane } \\
\text { r2; HMB-45, human melanoma black-45; IMP3, insulin-like } \\
\text { 13, phospho-Histone3; PR, progesterone receptor; SMA, sm }\end{array}$ & $\begin{array}{l}\text { cinoma in situ; PASH, pseudoangiomatous strc } \\
\text { els; CDX2, homeobox protein CDX2; SPC, solid } \\
\text { antigen; ER, estrogen receptor; GATA3, GATA } \\
\text { e growth factor II mRNA binding protein 3; ME } \\
\text { looth muscle actin; SMMHC, smooth muscle m }\end{array}$ & $\begin{array}{l}\text { erplasia; AR, andr } \\
\text { carcinoma; CK, cy } \\
\text { Protein 3; GCDFP- } \\
\text { oithelial cell; PAP, } \\
\text { avy chain; Melan- }\end{array}$ & $\begin{array}{l}\text { or; BCL2, B-cell lymphoma protein 2; CA 125, can } \\
\text { P, intraductal papilloma; EPC, encapsulated papill } \\
\text { stic disease fluid protein 15; HER2, human epidern } \\
\text { d phosphatase; PSA, prostate specific antigen; PAX } \\
\text { antigen; SOX10, sry-related HMG-BOX gene 10; } T\end{array}$ \\
\hline
\end{tabular}

1 , thyroid transcription factor- 1 ; WT1, Wilm's tumor 1 protein. 


\section{Disclosure statement}

No potential conflict of interest was reported by the authors.

\section{ORCID}

F. Rodrigues (D) http://orcid.org/0000-0001-8405-4249

J. Liberal (1) http://orcid.org/0000-0003-0161-9617

\section{References}

Abdel-Fatah TMA, Powe DG, Hodi Z, Reis-Filho JS, Lee AHS, Ellis IO. 2008. Morphologic and molecular evolutionary pathways of low nuclear grade invasive breast cancers and their putative precursor lesions: further evidence to support the concept of low nuclear grade breast neoplasia family. Am J Surg Pathol. 32:513-523. doi:10.1097/PAS.0b013e318161d1a5.

Abdelrahman T, Young P, Kozyar O, Davies E, Dojcinov S, Mansel RE. 2015. Giant pseudoangiomatous stromal hyperplasia presenting in the breast of a prepubertal child. Br Med J Case Rep. 2015:1-4.

Abdelwahab K, Hamdy O, Zaky M, Megahed N, Elbalka S, Elmetwally M, Denewer A. 2018. Breast fibromatosis, an unusual breast disease. J Surg Case Rep. 12:1-3.

Acs G, Lawton TJ, Rebbeck TR, LiVolsi VA, Zhang PJ. 2001. Differential Expression of E-cadherin in lobular and ductal neoplasms of the breast and its biologic and diagnostic implications. Am J Clin Pathol. 115:85-98. doi:10.1309/ FDHX-L92R-BATQ-2GE0.

Agarwal S, Singh A, Bagga P. 2018. Immunohistochemical evaluation of lymphovascular invasion in carcinoma breast with CD34 and D2-40 and its correlation with other prognostic markers. Ind J Pathol Microbiol. 61:39-44. doi:10.4103/IJPM.IJPM_791_16.

Agoumi M, Giambattista J, Hayes MM. 2016. Practical considerations in breast papillary lesions: a review of the literature. Arch Pathol Lab Med. 140:770-790. doi:10.5858/ arpa.2015-0525-RA.

Altaf FJ, Mokhtar GA, Emam E, Bokhary RY, Mahfouz NB, Al Amoudi S, AL-Gaithy ZK. 2014. Metaplastic carcinoma of the breast: an immunohistochemical study. Diagn Pathol. 9:1-10. doi:10.1186/1746-1596-9-139.

Anothaisintawee T, Wiratkapun C, Lerdsitthichai P, Kasamesup V, Wongwaisayawan S, Srinakarin J, Hirunpat S, Woodtichartpreecha $\mathrm{P}$, Boonlikit S, Teerawattananon $\mathrm{Y}$, Thakkinstian A. 2013. Risk factors of breast cancer: a systematic review and meta-analysis. Asia-Pac J Publ Health. 25:368-387. doi:10.1177/1010539513488795.

Apple SK. 2016. Sentinel lymph node in breast cancer: review article from a pathologist's point of view. J Pathol Transl Med. 50:83-95.

Ashoor A, Monti S, Pezzella M. 2017. Fibromatosis, a benign breast disease mimicking carcinoma. Int J Surg Case Rept. 41:392-397. doi:10.1016/j.ijscr.2017.11.017.

Aydiner A, Soran A, Igci A. 2016. Breast disease: diagnosis and pathology. Cham (Switzerland): Springer; p. 187-202.

Aytaç HÖ, Bolat FA, Canpolat T, Pourbagher A. 2015. Myofibroblastoma of the breast. J Breast Health. 11:192-194. doi:10.5152/tjbh.2015.2655.
Badve S, Gökmen-Polar Y. 2016. Molecular pathology of breast cancer. 1st ed. Cham (Switzerland): Springer; p. 81-94. http://link.springer.com/10.1007/978-3-319-41761-5

Bellezza G, Prosperi E, Del Sordo R, Colella R, Rulli A, Sidoni A. 2016. IMP3 is strongly expressed in malignant phyllodes tumors of the breast: an immunohistochemical study. Int J Surg Pathol. 24:37-42. doi:10.1177/ 1066896915603119.

Bhat V, Raju P, Rao S, Ramaiah S. 2015. Infantile fibromatosis: a rare cause of anterior mediastinal mass in a child. J Clin Imag Sci. 5:34-37. doi:10.4103/2156-7514.159452.

Bishop JA, Sharma R, Illei PB. 2010. Napsin A and thyroid transcription factor-1 expression in carcinomas of the lung, breast, pancreas, colon, kidney, thyroid, and malignant mesothelioma. Hum Pathol. 41:20-25. doi:10.1016/j. humpath.2009.06.014.

Bombonati A, Lerwill MF. 2012. Metastases to and from the breast. Surg Pathol Clin. 5:719-747. doi:10.1016/j. path.2012.06.004.

Bowman E, Oprea G, Okoli J, Gundry K, Rizzo M, GabramMendola S, Manne U, Smith G, Pambuccian S, Bumpers HL. 2012. Pseudoangiomatous stromal hyperplasia (PASH) of the breast: a series of 24 patients. Breast J. 18:242-247. doi:10.1111/j.1524-4741.2012.01230.x.

Bratthauer GL, Moinfar F, Stamatakos MD, Mezzetti TP, Shekitka KM, Man YG, Tavassoli FA. 2002. Combined E-cadherin and high molecular weight cytokeratin immunoprofile differentiates lobular, ductal, and hybrid mammary intraepithelial neoplasias. Hum Pathol. 33:620-627. doi:10.1053/hupa.2002.124789.

Brouckaert O, Paridaens R, Floris G, Rakha E, Osborne K, Neven P. 2012. A critical review why assessment of steroid hormone receptors in breast cancer should be quantitative. Ann Oncol. 24:46-53.

Busam K, Jungbluth A. 1999. Melan-A, a new melanocytic differentiation marker. Adv Anat Pathol. 6:12-18. doi:10.1097/00125480-199901000-00002.

Carter MR, Hornick JL, Lester S, Fletcher CDM. 2006. Spindle cell (sarcomatoid) carcinoma of the breast: a clinicopathologic and immunohistochemical analysis of 29 cases. Am J Surg Pathol. 30:300-309. http://www.ncbi. nlm.nih.gov/pubmed/16538049.

Charalampoudis P, Markopoulos C. 2018. Controversies and recommendations regarding sentinel lymph node biopsy in primary breast cancer: a comprehensive review of current data. Eur J Surg Oncol. 44:5-14. doi:10.1016/j.ejso.2017.10.215.

Charu V, Cimino-Mathews A. 2017. Spindle-cell lesions of the breast. Am J Surg Pathol. 22:116-123.

Cheah AL, Billings SD, Rowe JJ. 2016. Mesenchymal tumours of the breast and their mimics: a review with approach to diagnosis. Pathology. 48:406-424. doi:10.1016/j.pathol.2016.02.018.

Cheng CW, Chan LW, Ng CF, Chan CK, Tse MKG, Lai MMF. 2006. Breast metastasis from prostate cancer and interpretation of immunoreactivity to prostate-specific antigen. Int J Urol. 13:463-465. doi:10.1111/j.1442-2042.2006.01327.x.

Chu PG, Weiss LM. 2004. Immunohistochemical characterization of signet-ring cell carcinomas of the stomach, breast, and colon. Am J Clin Pathol. 121:884-892. doi:10.1309/A09ERYMFR64NERDW. 
Cimino-Mathews A, Subhawong AP, Elwood $\mathrm{H}$, Warzecha HN, Sharma R, Park BH, Taube JM, Illei PB, Argani P. 2013. Neural crest transcription factor Sox10 is preferentially expressed in triple-negative and metaplastic breast carcinomas. Hum Pathol. 44:959-965. doi:10.1016/j. humpath.2012.09.005.

Cimino-Mathews A, Sharma R, Illei PB, Vang R, Argani P. 2014. A subset of malignant phyllodes tumors express p63 and p40: a diagnostic pitfall in breast core needle biopsies. Am J Surg Pathol. 38:1689-1696. doi:10.1097/ PAS.0000000000000115.

Coates AS, Winer EP, Goldhirsch A, Gelber RD, Gnant M, Piccart-Gebhart M, Thürlimann B, Senn H-J. 2015. Tailoring therapies-improving the management of early breast cancer: st. Gallen international expert consensus on the primary therapy of early breast cancer 2015. Ann Oncol. 26:1533-1546. http://www.pubmedcentral.nih.gov/articleren der.fcgi? artid $=4511219$ andtool $=$ pmcentrezandrendertype $=$ abstract.

Dabbs DJ, Kaplai M, Chivukula M, Kanbour A, KanbourShakir A, Carter GJ. 2007a. The spectrum of morphomolecular abnormalities of the E-cadherin/catenin complex in pleomorphic lobular carcinoma of the breast. Appl Immunohistochem Mol Morphol. 15:260-266. http:// www.ncbi.nlm.nih.gov/pubmed/17721269.

Dabbs DJ, Bhargava R, Chivukula M. 2007b. Lobular versus ductal breast neoplasms. Am J Surg Pathol. 31:427-437. http://content.wkhealth.com/linkback/openurl? sid= WKPTLP:landingpageandan=00000478-200703000-00012.

Dako. 2014. Interpretation Manual-breast Cancer. Denmark: Glostrup; p. 14-16.

Darb-Esfahani S, von Minckwitz G, Denkert C, Ataseven B, Hogel B, Mehta K, Kaltenecker G, Rudiger T, Pfitzner B, Kittel K, Fiedler B, Baumann K, Moll R, Dietel M, Eidtmann H, Thomssen C, Loibl S. 2014. Gross cystic disease fluid protein 15 (GCDFP-15) expression in breast cancer subtypes. BioMed Cent Cancer. 14:1-10. http:// www.ncbi.nlm.nih.gov/pubmed/25070172.

Dekate JP, Chetty R, Walsh J, Perez-Ordoñez B. 2015. Epithelioid myofibroblastoma of the female breast. Diagn Histopathol. 21:299-302. doi:10.1016/j.mpdhp.2015.06.017.

Denkert C, Budczies J, von Minckwitz G, Wienert S, Loibl S, Klauschen F. 2015. Strategies for developing Ki67 as a useful biomarker in breast cancer. Breast. 24:S67-S72. doi:10.1016/j.breast.2015.07.017.

Dennis JL, Hvidsten TR, Wit EC, Komorowski J, Bell AK, Downie I, Mooney J, Bellamy C, Keith WN, Oien KA. 2005. Markers of adenocarcinoma characteristic of the site of origin: development of a diagnostic algorithm. Clin Cancer Res. 11:3766-3773.

Dewar R, Fadare O, Gilmore H, Gown AM. 2011. Best practices in diagnostic immunohistochemistry. Arch Pathol Lab Med. 135:422-429.

Dileep A, Prasad P. 2018. Use of immunomarkers D2-40 and CD31 in detection of lymphovascular invasion in breast carcinoma. J Med Sci Clin Res. 6:90-96.

Dirbas F. 2011. Breast surgical techniques and interdisciplinary management. 1st. Dirbas F, Scott-Conner C, Eds. New York: Springer-Verlag; p. 613-616.

Drinka EK, Bargaje A, Patel P, Salhadar A, Sinacore J, Rajan P. 2012. Pseudoangiomatous stromal hyperplasia (PASH) of the breast: a clinicopathological study of 79 cases. Int J Surg Pathol. 20:54-58. doi:10.1177/ 1066896911418643.

Dunne B, Lee AHS, Pinder SE, Bell JA, Ellis IO. 2003. An immunohistochemical study of metaplastic spindle cell carcinoma, phyllodes tumor and fibromatosis of the breast. Hum Pathol. 34:1009-1015. doi:10.1053/S00468177(03)00414-3.

Early Breast Cancer Trialists' Collaborative Group. 2005. Effects of chemotherapy and hormonal therapy for early breast cancer on recurrence and 15-year survival: an overview of the randomised trials. Lancet. 365:1687-1717. doi:10.1016/S0140-6736(05)66544-0.

Eliyatkin N, Yalcin E, Zengel B, Aktaş S, Vardar E. 2015. Molecular Classification of breast carcinoma: from traditional, old-fashioned way to a new age, and a new way. J Breast Health. 11:59-66. http://www.thejournalof breasthealth.com/sayilar/40/buyuk/59-66.pdf.

Elledge RM, Green S, Ciocca D, Pugh R, Allred DC, Clark GM, Hill J, Ravdin P, O'Sullivan J, Martino S, Osborne CK. 1998. HER-2 expression and response to tamoxifen in estrogen receptor-positive breast cancer: a Southwest oncology group study. Clin Cancer Res. 4:7-12.

Ellis CL, Chang AG, Cimino-Mathews A, Argani P, Youssef RF, Kapur P, Montgomery EA, Epstein JI. 2013. GATA-3 Immunohistochemistry in the differential diagnosis of adenocarcinoma of the urinary bladder. Am J Surg Pathol. 37:1756-1760.

Esposito NN, Mohan D, Brufsky A, Lin Y, Kapali M, Dabbs DJ. 2006. Phyllodes tumor: a clinicopathologic and immunohistochemical study of 30 cases. Arch Pathol Lab Med. 130130:1516-1521.

Esposito NN, Dabbs DJ, Bhargava R. 2009. Are encapsulated papillary carcinomas of the breast in situ or invasive? A basement membrane study of 27 cases. Am J Clin Pathol. 131:228-242. doi:10.1309/AJCP8A2UVLCYGTPU.

Fayed YM, El-Sheikh SA-M, Abulkheir ILH, Khorshed INA-H. 2012. Immunohistochemical expression of p27 in ductal carcinoma of breast and its correlation with HER2/neu expression and hormonal status. Egypt J Pathol. 32:33-41. http:// ovidsp.ovid.com/ovidweb.cgi? T=JSand CSC= YandNEWS $=$ NandPAGE $=$ fulltextandD $=$ ovftnand $A N=$ 01547795-201207000-00006

Filie AC, Simsir A, Fetsch P, Abati A. 2002. Melanoma metastatic to the breast- utility of fine needle aspiration and immunohistochemistry. Acta Cytol. 46:13-18. doi:10.1159/000326709.

Foulkes WD, Reis-Filho JS, Narod SA. 2010. Tumor size and survival in breast cancer-a reappraisal. Nat Rev Clin Oncol. 7:348-353. http://www.nature.com/doifinder/10.1038/nrcli nonc. 2010.39 .

Fritzsche FR, Thomas A, Winzer K, Beyer B, Dankof A, Bellach J, Dahl E, Dietel M, Kristiansen G. 2007. Coexpression and prognostic value of gross cystic disease fluid protein 15 and mammaglobin in primary breast cancer. Histol Histopathol. 1996:1221-1230.

Gao S, Ma -J-J, Lu C. 2013. Prognostic value of cyclin E expression in breast cancer: a meta-analysis. Tumor Biol. 34:3423-3430. http://link.springer.com/10.1007/ s13277-013-0915-8.

Gennari A, Sormani MP, Pronzato P, Puntoni M, Colozza M, Pfeffer U, Bruzzi P. 2008. HER2 status and efficacy of 
adjuvant anthracyclines in early breast cancer: a pooled analysis of randomized trials. J Natl Cancer Inst. 100:14-20. doi:10.1093/jnci/djm252.

Ghoncheh M, Pournamdar Z, Salehiniya H. 2016. Incidence and mortality and epidemiology of breast cancer in the world. Asian Pac J Cancer Prev. 17:43-46. doi:10.7314/ apjcp.2016.17.4.2119.

Ginter PS, D'Alfonso TM. 2017. Current concepts in diagnosis, molecular features, and management of lobular carcinoma in situ of the breast with a discussion of morphologic variants. Arch Pathol Lab Med. 141:1668-1678:arpa.2016-0421-RA. http://www.archivesofpathology.org/doi/10.5858/arpa.20160421-RA.

Giobuin S, Kavanagh D, Myers E, Doherty A, Quinn C, Crotty T, Evoy D, Mcdermott E. 2011. The significance of immunohistochemistry positivity in sentinel nodes which are negative on haematoxylin and eosin in breast cancer. Eur J Surg Oncol. 35:1257-1260. doi:10.1016/j. ejso.2009.04.004.

Goldhirsch A, Ingle JN, Gelber RD, Coates AS, Thürlimann B, Senn HJ. 2009. Thresholds for therapies: highlights of the St. Gallen international expert consensus on the primary therapy of early breast cancer 2009. Ann Oncol. 20:1319-1329. doi:10.1093/annonc/mdp322.

Goldhirsch A, Wood WC, Coates AS, Gelber RD, Thürlimann B, Senn HJ. 2011. Strategies for subtypes-dealing with the diversity of breast cancer: highlights of the St. Gallen international expert consensus on the primary therapy of early breast cancer 2011. Ann Oncol. 22:1736-1747. doi:10.1093/annonc/mdq731.

Goldhirsch A, Winer EP, Coates AS, Gelber RD, PiccartGebhart M, Thürlimann B, Senn HJ. 2013. Personalizing the treatment of women with early breast cancer: highlights of the St. Gallen international expert consensus on the primary therapy of early breast cancer 2013. Ann Oncol. 24:2206-2223. doi:10.1093/annonc/mdt303.

Gomez-Fernandez C, Mejias A, Walker G, Nadji M. 2010. Immunohistochemical expression of estrogen receptor in adenocarcinomas of the lung: the antibody factor. Appl Immunohistochem Mol Morphol. 18:137-141. doi:10.1097/ PAI.0b013e3181bec23b.

Gong Y, Liu Y-R, Ji P, Hu X, Shao Z-M. 2017. Impact of molecular subtypes on metastatic breast cancer patients: a SEER population-based study. Sci Rept. 7:45411. http:// www.nature.com/articles/srep45411.

Gorringe KL, Fox SB. 2017. Ductal carcinoma in situ biology, biomarkers, and diagnosis. Front Oncol. 7:248. http://journal.frontiersin.org/article/10.3389/fonc.2017. 00248/full.

Gown AM, Fulton RS, Kandalaft PL. 2016. Markers of metastatic carcinoma of breast origin. Histopathology. 68:86-95. doi:10.1111/his.12877.

Grabowski J, Salzstein SL, Sadler GR, Blair S. 2008. Intracystic papillary carcinoma: a review of 917 cases. Cancer. 113:916-920. doi:10.1002/cncr.23723.

Grin A, O'Malley FP, Mulligan AM. 2009. Cytokeratin 5 and estrogen receptor immunohistochemistry as a useful adjunct in identifying atypical papillary lesions on breast needle core biopsy. Am J Surg Pathol. 33:1615-1623. doi:10.1097/PAS.0b013e3181aec446.

Gujam FJA, Going JJ, Edwards J, Mohammed ZMA, McMillan DC. 2014. The role of lymphatic and blood vessel invasion in predicting survival and methods of detection in patients with primary operable breast cancer. Crit Rev Oncol/Hematol. 89:231-241. doi:10.1016/j. critrevonc.2013.08.014.

Hammond MEH, Hayes DF, Dowsett M, Allred DC, Hagerty KL, Badve S, Fitzgibbons PL, Francis G, Goldstein NS, Hayes M, Hicks DG, Lester S, Love R, Mangu PB, McShane L, Miller K, Osborne K, Paik S, Perlmutter J, Rhodes A, Sasano H, Schwartz JN, Sweep FG, Taube S, Torlakovic E, Valenstein P, Viale G, Visscher D, Wheeler T, Williams RB, Wittliff JL, Wolff AC. 2010. American Society of clinical oncology/ college of american pathologists guideline recommendations for immunohistochemical testing of estrogen and progesterone receptors in breast cancer. Arch Pathol Lab Med. 134:e48-e72.

He H, Gonzalez A, Robinson E, Yang WT. 2014. Distant metastatic disease manifestations in infiltrating lobular carcinoma of the breast. Am J Roentgenol. 202:1140-1148 doi:10.2214/AJR.13.10688.

Hicks DG, Lester SC. 2016. Diagnostic pathology breast. 2nd ed. Salt Lake City (UT): Elsevier; p. 386-390, 422-424, 474-475, 546-551, 624-629.

Hill CB, Yeh IT. 2005. Myoepithelial cell staining patterns of papillary breast lesions: from intraductal papillomas to invasive papillary carcinomas. Am J Clin Pathol. 123:36-44. doi:10.1309/XG7TPQ16DMJAV8P1.

Honma N, Horii R, Iwase T, Saji S, Younes M, Ito Y, Akiyama F. 2014. Proportion of estrogen or progesterone receptor expressing cells in breast cancers and response to endocrine therapy. Breast. 23:754-762. doi:10.1016/j. breast.2014.08.003.

Howitt BE, Fletcher CDM. 2016. Mammary-type myofibroblastoma: clinicopathologic characterization in a series of 143 cases. Am J Surg Pathol. 40:361-367. doi:10.1097/PAS.0000000000000540.

Ibrahim HAH, Shousha S. 2013. Myofibroblastoma of the female breast with admixed but distinct foci of spindle cell lipoma: a case report. Case Rep Pathol. 2013:1-5.

Ibrahim WS. 2011. Comparison of stromal CD10 expression in benign, borderline, and malignant phyllodes tumors among Egyptian female patients. Ind J Pathol Microbiol. 54:741-744.

Ichihara S, Fujimoto T, Hashimoto K, Moritani S, Hasegawa M, Yokoi T. 2007. Double immunostaining with p63 and high-molecular-weight cytokeratins distinguishes borderline papillary lesions of the breast. Pathol Int. 57:126-132. doi:10.1111/pin.2007.57.issue-3.

Inoue $M$, Nakagomi $H$, Nakada $H$, Furuya K, Ikegame K, Watanabe H, Omata M, Oyama T. 2017. Specific sites of metastases in invasive lobular carcinoma: a retrospective cohort study of metastatic breast cancer. Breast Cancer. 24:667-672. doi:10.1007/s12282-017-0753-4.

Iqbal N, Iqbal N. 2014. Human epidermal growth factor receptor 2 (HER2) in cancers: overexpression and therapeutic implications. Mol Biol Int. 2014:1-9. http:// www.hindawi.com/journals/mbi/2014/852748/.

Jacobs C, Ibrahim MFK, Clemons M, Hutton B, Simos D, Caudrelier JM, Graham ID, Smith S, Addison C, Arnaout A. 2015. Treatment choices for patients with invasive lobular breast cancer: a doctor survey. J Eval Clin Pract. 21:740-748. doi:10.1111/jep.12256.

Jemal A, Bray F, Center MM, Ferlay J, Ward E, Forman D. 2011. Global cancer statistics. CA Cancer J Clin. 61:69-90. 
http://www.ncbi.nlm.nih.gov/entrez/query.fcgi? $\mathrm{cmd}=$ Retrieveanddb $=$ PubMedanddopt $=$ Citationandlist_uids $=$ 10200776.

Jing Q-Y, Liu L, Zhong B, Zhu L-H, Chen Z-Y, Liu W, Y-N W, Wei B. 2017. Mammary epithelioid myofibroblastoma mimicking invasive carcinoma: case report and literature review. Int J Clin Exp Pathol. 10:10640-10646. https://www. scopus.com/inward/record.uri? e id $=2-\mathrm{s} 2$. $0-85032581398$ and partner ID $=40$ and md $5=$ $6 \mathrm{cb} 3 \mathrm{c} 4709 \mathrm{ec} 61543 \mathrm{c} 38 \mathrm{a} 9245 \mathrm{dc} 4 \mathrm{~d} 091 \mathrm{~b}$

Jorns JM. 2016. Papillary lesions of the breast: a practical approach to diagnosis. Arch Pathol Lab Med. 140:1052-1059. http://www.archivesofpathology.org/doi/ 10.5858/arpa.2016-0219-RA.

Kafadar MT, Yalçın M, Gök MA, Aktaş A, Yürekli TS, Arslan Aİ. 2017. Intraparenchymal leiomyoma of the breast: a rare location for an infrequent tumor. Eur $\mathrm{J}$ Breast Health. 13:156-158.

Karabacak T, Eğ̊lmez R, Arpacı RB, Pfeiffer ES. 2011. $\beta$ Catenin expression in in situ and infiltrative ductal carcinomas of the breast. Turk Patoloji Derg. 27:185-188.

Khazai L, Rosa M. 2015. Use of immunohistochemical stains in epithelial lesions of the breast. Cancer Control. 22:220-225. doi:10.1177/107327481502200214.

Kidwai N, Gong Y, Sun X, Deshpande CG, Yeldandi AV, Rao MS, Badve S. 2003. Expression of androgen receptor and prostate-specific antigen in male breast carcinoma. Breast Cancer Res. 6:18-23. doi:10.1186/bcr733.

Kim KI, Lee KH, Kim TR, Chun YS, Lee TH, Park HK. 2014. $\mathrm{Ki}-67$ as a predictor of response to neoadjuvant chemotherapy in breast cancer patients. J Breast Cancer. 17:40-46. doi:10.4048/jbc.2014.17.1.40.

Kim S, Park HK, Jung HY, Lee S-Y, Min K-W, Kim WY, Han HS, Kim WS, Hwang TS, Lim SD. 2013. ERG Immunohistochemistry as an endothelial marker for assessing lymphovascular invasion. Kor J Pathol. 47:355-364. doi:10.4132/KoreanJPathol.2013.47.4.355.

Koker MM, Kleer CG, Page DL, Goulart RA, Pisano ED, Fajardo LL, Berg WA, Caudry DJ, McNeil BJ, Schnitt SJ. 2004. P63 expression in breast cancer. Am J Surg Pathol. 28:1506-1512. http://content.wkhealth.com/linkback/open url? sid =WKPTLP:landingpageand an $=00000478$ 200411000-00012.

Koo JS, Jung W, Kim H. 2010. Epithelial displacement into the lymphovascular space can be seen in breast core needle biopsy specimens. Am J Clin Pathol. 133:781-787.

Korcheva VB, Levine J, Beadling C, Warrick A, Countryman G, Olson NR, Heinrich MC, Corless CL, Troxell ML. 2011. Immunohistochemical and molecular markers in breast phyllodes tumors. Appl Immunohistochem Mol Morphol. 19:119-125. http://content.wkhealth.com/linkback/openurl? sid=WKPTLP:landingpageandan $=00129039-201103000$ 00006.

Krawczyk N, Fehm T, Ruckhäberle E, Mohrmann S, Riemer J, Braunstein S, Hoffmann J. 2016. Bilateral diffuse pseudoangiomatous stromal hyperplasia (PASH) causing gigantomastia in a 33-year-old pregnant woman: case report. Breast Care. 11:356-358. doi:10.1159/000450867.

Kuba MG, Lester SC, Giess CS, Bertagnolli MM, Wieczorek TJ, Brock JE. 2017. Fibromatosis of the breast diagnostic accuracy of core needle biopsy. Am J Clin Pathol. 148:243-250 doi:10.1093/ajcp/aqx065.
Kuroda N, Fujishima N, Hayes MM, Moritani S, Ichihara S. 2014. Encapsulated papillary carcinoma, apocrine type, of the breast. Malay J Pathol. 36:139-143.

Lacroix-Triki M, Mery E, Voigt -J-J, Istier L, Rochaix P. 2003. Value of cytokeratin 5/6 immunostaining using D5/16 B4 antibody in the spectrum of proliferative intraepithelial lesions of the breast. A comparative study with 34betaE12 antibody. Virchows Arch. 442:548-554. http:// www.ncbi.nlm.nih.gov/pubmed/12712335.

Lacroix-Triki M, Geyer FC, Lambros MB, Savage K, Ellis IO, Lee AHS, Reis-Filho JS. 2010. $\beta$-catenin/Wnt signalling pathway in fibromatosis, metaplastic carcinomas and phyllodes tumours of the breast. Mod Pathol. 23:1438-1448. doi:10.1038/modpathol.2010.141.

Lakhani SR, Ellis IO, Schnitt SJ, Tan PH, van de Vijver MJ. 2012. WHO classification of tumours of the beast. Lyon (France): International Agency for Research on Cancer.

Lehr HA, Folpe A, Yaziji H, Kommoss F, Gown AM. 2000. Cytokeratin 8 immunostaining pattern and E-cadherin expression distinguish lobular from ductal breast carcinoma. Am J Clin Pathol. 114:190-196. doi:10.1309/ X559-FDJB-LJGD-YG7E.

Leitzel K, Teramoto Y, Konrad K, Chinchilli VM, Volas G, Grossberg H, Harvey H, Demers L, Lipton A. 1995. Elevated serum c-erbB-2 antigen levels and decreased response to hormone therapy of breast cancer. J Clin Oncol. 13:1129-1135. doi:10.1200/ JCO.1995.13.5.1129.

Lerwill MF. 2004. Current practical applications of diagnostic immunohistochemistry in breast pathology. Am J Surg Pathol. 28:1076-1091.

Li X, Schwartz MR, Ro J, Hamilton CR, Ayala AG, Truong LD, Zhai QJ. 2014. Diagnostic utility of E-cadherin and P120 catenin cocktail immunostain in distinguishing DCIS from LCIS. Int J Clin Exp Pathol. 7:2551-2557.

Lin F, Prichard J, Wilkerson M. 2015. Handbook of practical immunohistochemistry. New York: Springer-Verlag; p. 203-204. http://link.springer.com/10.1007/978-1-4939-1578-1.

Lin F, Zhang J, Liu H. 2017. Handbook of practical fine needle aspiration and small tissue biopsies. Cham (Switzerland): Springer International Publishing; p. 222-223.

Lipton A, Ali SM, Leitzel K, Demers L, Harvey HA, ChaudriRoss HA, Brady C, Wyld P, Carney W. 2003. Serum HER-2/neu and response to the aromatase inhibitor letrozole versus tamoxifen. J Clin Oncol. 21:1967-1972. doi:10.1200/JCO.2003.09.098.

Liu H. 2014. Application of immunohistochemistry in breast pathology: a review and update. Arch Pathol Lab Med. 138:1629-1642. doi:10.5858/arpa.2013-0455-OA.

Liu N, Yang Z, Liu X, Niu Y. 2017. Lymph node status in different molecular subtype of breast cancer: triple negative tumours are more likely lymph node negative. Oncotarget. 8:55534-55543. http://www.oncotarget.com/ fulltext/15022.

Ly A, Lester SC, Dillon D. 2012. Prognostic factors for patients with breast cancer: traditional and new. Surg Pathol Clin. 5:775-785. doi:10.1016/j.path.2012.06.010.

Magro G. 2017. Differential diagnosis of benign spindle cell lesions. Surg Pathol Clin. 11:91-121. doi:10.1016/j. path.2017.09.005. 
Martinez AP, Cohen C, Hanley KZ, Li X. 2016. Estrogen receptor and cytokeratin 5 are reliable markers to separate usual ductal hyperplasia from atypical ductal hyperplasia and low-grade ductal carcinoma in situ. Arch Pathol Lab Med. 140:686-689. doi:10.5858/arpa.20150238-OA.

Mass RD, Press MF, Anderson S, Cobleigh MA, Vogel CL, Dybdal N, Leiberman G, Slamon DJ. 2005. Evaluation of clinical outcomes according to HER2 detection by fluorescence in situ hybridization in women with metastatic breast cancer treated with trastuzumab. Clin Breast Cancer. 6:240-246. doi:10.3816/CBC.2005.n.026.

Mathew A, Rajagopal PS, Villgran V, Sandhu GS, Jankowitz RC, Jacob M, Rosenzweig M, Oesterreich S, Brufsky A. 2017. Distinct pattern of metastases in patients with invasive lobular varcinoma of the breast. Geburts Frauenheilkd. 77:660-666. doi:10.1055/s-0043-109374.

Metry M, Shaaban M, Youssef M, Carr M, Presentation C 2016. Myofibroblastoma of the breast: literature review and case report. Case Rep Oncol Med. 2016:15-18. http://www.medscape.com/viewarticle/877813_3

Miettinen M, Mccue PA, Sarlomo-rikala M, Waloszczyk P, Biernat W, Lasota J, Wang Z. 2014. GATA3: a multispecific but potentially useful marker in surgical pathology. Am J Surg Pathol. 38:13-22. doi:10.1097/ PAS.0000000000000115.

Mittendorf EA, Philips AV, Meric-bernstam F, Qiao N, Wu Y, Harrington S, Su X, Wang Y, Gonzalez-angulo AM, Akcakanat A, Chawla A, Curran M, Hwu P, Sharma P, Litton JK, Molldrem JJ, Alatrash G. 2014. PD-L1 expression in triple-negative breast cancer. Cancer Immunol Res. 2:361-370. doi:10.1158/2326-6066.CIR-13-0163.

Mohammed RAA, Martin SG, Gill MS, Green AR, Paish EC, Ellis IO. 2007. Improved methods of detection of lymphovascular invasion demonstrate that it is the predominant method of vascular invasion in breast vancer and has important clinical consequences. Am J Surg Pathol. 31:1825-1833. doi:10.1097/PAS.0b013e31806841f6.

Moinfar F, Man YG, Lininger RA, Tavassoli FA. 1999. Use of keratin $34 \mathrm{bE} 12$ as an adjunct in the diagnosis of mammary intraepithelial neoplasia ductal type-benign and malignant intraductal proliferations. Am J Surg Pathol. 23:1048-1058. doi:10.1097/00000478-199909000-00007.

Moore T, Lee AHS. 2001. Expression of CD34 and bcl-2 in phyllodes tumours, fibroadenomas and spindle cell lesions of the breast. Histopathology. 38:62-67. doi:10.1046/ j.1365-2559.2001.01053.x.

Mugler KC, Marshall C, Hardesty L, Finlayson C, Singh M. 2007. Intracystic papillary carcinoma of the breast: differential diagnosis and management. Oncology. 21:1-8.

Myong N, Min J. 2016. Low-grade myofibroblastic sarcoma arising in fibroadenoma of the breast-a case report. Diagn Pathol. 11:1-7. doi:10.1186/s13000-016-0480-8.

Nassar A, Sookhan N, Santisteban M, Bryant SC, Boughey JC, Giorgadze T, Degnim A. 2010. Diagnostic utility of snail in metaplastic breast carcinoma. Diagn Pathol. 5:1-10. http:// www.diagnosticpathology.org/content/5/1/76.

Nicolini A, Ferrari P, Duffy MJ. 2017. Prognostic and predictive biomarkers in breast cancer: past, present and future. Sem Cancer Biol. 52:56-73. doi:10.1016/j. semcancer.2017.08.010.
Nofech-mozes S, Holloway C, Hanna W. 2008. The role of cytokeratin $5 / 6$ as an adjunct diagnostic tool in breast core needle biopsies. Int J Surg Pathol. 16:6-9. doi:10.1177/ 1066896908316901.

Nonaka D, Chiriboga L, Soslow RA. 2008. Expression of Pax8 as a useful marker in distinguishing ovarian carcinomas from mammary carcinomas. Am J Surg Pathol. 32:1566-1571. http://content.wkhealth.com/linkback/open url? sid =WKPTLP:landing pageand an $=00000478$ 200810000-00017.

Noronha Y, Raza A, Hutchins B, Chase D, Garberoglio C, Chu P, Weiss L, Wang J. 2011. CD34, CD117, and Ki-67 expression in phyllodes tumor of the breast: an immunohistochemical study of 33 cases. Int J Surg Pathol. 19:152-158. doi:10.1177/1066896910382009.

O'Connell FP, Wang HH, Odze RD. 2005. Utility of immunohistochemistry in distinguishing primary adenocarcinomas from metastatic breast carcinomas in the gastrointestinal tract. Arch Pathol Lab Med. 129:338-347.

Ohsie SJ, Sarantopoulos GP, Cochran AJ, Binder SW. 2008. Immunohistochemical characteristics of melanoma. J Cutan Pathol. 35:433-444. doi:10.1111/j.1600-0560.2007.00891.x.

Otsuki Y, Yamada M, Shimizu S, Suwa K, Yoshida M, Tanioka F, Ogawa H, Nasuno H, Serizawa A, Kobayashi H. 2007. Solid papillary carcinoma of the breast: clinicopathological study of 20 cases. Pathol Int. 57:421-429. http://doi.wiley.com/10.1111/ j.1440-1827.2007.02118.x.

Otterbach F, Bànkfalvi À, Bergner S, Decker T, Krech R, Boecker W. 2000. Cytokeratin 5/6 immunohistochemistry assists the differential diagnosis of atypical proliferations of the breast. Histopathology. 37:232-240. doi:10.1046/ j.1365-2559.2000.00882.x.

Penault-Llorca F, Bilous M, Dowsett M, Hanna W, Osamura RY, Rüschoff J, Van De Vijver M. 2009. Emerging technologies for assessing HER2 amplification. Am J Clin Pathol. 132:539-548. doi:10.1309/ AJCPV2I0HGPMGBSQ.

Peng Y, Butt YM, Chen B, Zhang X, Tang P. 2017. Update on Immunohistochemical analysis in breast lesions. Arch Pathol Lab Med. 141:1033-1051. http://www.archivesof pathology.org/doi/10.5858/arpa.2016-0482-RA.

Pezzi CM, Patel-Parekh L, Cole K, Franko J, Klimberg VS, Bland K. 2007. Characteristics and treatment of metaplastic breast cancer: analysis of 892 cases from the national cancer data base. Ann Surg Oncol. 14:166-173. doi:10.1245/s10434-006-9124-7.

Popnikolov NK, Cavone SM, Schultz PM, Garcia FU. 2005. Diagnostic utility of p75 neurotrophin receptor (p75NTR) as a marker of breast myoepithelial cells. Mod Pathol. 18:1535-1541. doi:10.1038/modpathol.3800487.

Press MF, Slamon DJ, Flom KJ, Park J, Zhou J-Y, Bernstein L. 2002. Evaluation of HER-2/neu gene amplification and overexpression: comparison of frequently used assay methods in a molecularly characterized cohort of breast cancer specimens. J Clin Oncol. 20:3095-3105. doi:10.1200/JCO.2002.09.094.

Pusztai L, Karn T, Safonov A, Abu-Khalaf MM, Bianchini G. 2016. New Strategies in breast cancer: immunotherapy. Cancer Immunol Res. 22:2105-2110.

Rabban JT, Koerner FC, Lerwill MF. 2006. Solid papillary ductal carcinoma in situ versus usual ductal hyperplasia in the breast: a potentially difficult distinction resolved by 
cytokeratin 5/6. Hum Pathol. 37:787-793. doi:10.1016/j. humpath.2006.02.016.

Rafeek N, Dev B, Thambidurai L, Satchidanandam A. 2017. Tumoral pseudoangiomatous stromal hyperplasia: radiological and pathological correlation with review of literature. Egypt J Radiol Nucl Med. 48:147-152. doi:10.1016/j.ejrnm.2016.10.008.

Rakha EA, Gandhi N, Climent F, van Deurzen CHM, Haider SA, Dunk L, Lee AHS, Macmillan D, Ellis IO. 2011. Encapsulated papillary carcinoma of the breast. Am J Surg Pathol. 35:1093-1103. http://content.wkhealth.com/ linkback/openurl? sid=WKPTLP:landingpageandan= 00000478-201108000-00001.

Rakha EA, Tun M, Junainah E, Ellis IO, Green A. 2012. Encapsulated papillary carcinoma of the breast: a study of invasion associated markers. J Clin Pathol. 65:710-714. doi:10.1136/jclinpath-2012-200710.

Rakha EA, Aleskandarany MA, Lee AHS, Ellis IO. 2016. An approach to the diagnosis of spindle cell lesions of the breast. Histopathology. 68:33-44. http://doi.wiley.com/10. 1111/his. 12865.

Rakha EA, Green AR. 2017. Molecular classification of breast cancer: what the pathologist needs to know. Pathology. 49:111-119.

Rakha EA, Coimbra ND, Hodi Z, Juneinah E, Ellis IO, Lee AHS. 2017. Immunoprofile of metaplastic carcinomas of the breast. Histopathology. 70:975-985. doi:10.1111/his.13159.

Rakha EA, Ellis IO. 2018. Diagnostic challenges in papillary lesions of the breast. Pathology. 50:100-110. doi:10.1016/j. pathol.2017.10.005.

Rebutini PZ, Vargas TGV, Medeiros F. 2017. Giant nodular pseudoangiomatous stromal hyperplasia of the breast with fibroadenomatoid myxoid changes: a potential pitfall in the differential diagnosis of phyllodes tumor. J Bras Patol Med Lab. 53:210-214.

Ren M, Kong Y, Cai X, Shen X, Lyu J. 2018. Application of sentinel lymph node biopsy in patients with melanoma. Chin J Pathol. 47:360-365.

Rosa FE, Santos RM, Rogatto SR, Domingues MAC. 2013. Chromogenic in situ hybridization compared with other approaches to evaluate HER2/neu status in breast carcinomas. Braz J Med Biol Res. 46:207-216. http:// www.ncbi.nlm.nih.gov/pubmed/23558859.

Rosa G, Dawson A, Rowe JJ. 2017. Does identifying whether pseudoangiomatous stromal hyperplasia (PASH) is focal or diffuse on core biopsy correlate with a PASH nodule on excision? Int J Surg Pathol. 25:292-297. doi:10.1177/ 1066896916676585.

Rosen PP. 2008. Rosen's Breast Pathology. 3rd ed. Philadelphia (PA): Lippincott, Williams and Wilkins; $\mathrm{p}$. 153-157.

Sasaki E, Tsunoda N, Hatanaka Y, Mori N, Iwata H, Yatabe Y. 2007. Breast-specific expression of MGB1/ mammaglobin: an examination of 480 tumors from various organs and clinicopathological analysis of MGB1-positive breast cancers. Mod Pathol. 20:208-214. doi:10.1038/modpathol.3800731.

Schwartz AM, Henson DE, Chen D, Rajamarthandan S. 2014. Histologic grade remains a prognostic factor for breast cancer regardless of the number of positive lymph nodes and tumor size: a study of 161708 cases of breast cancer from the SEER program. Arch Pathol Lab Med. 138:1048-1052. doi:10.5858/arpa.2013-0455-OA.

Seidman AD, Berry D, Cirrincione C, Harris L, Muss H, Marcom PK, Gipson G, Burstein H, Lake D, Shapiro CL, Ungaro P, Norton L, Winer E, Hudis C. 2008. Randomized phase III trial of weekly compared with every-3-weeks paclitaxel for metastatic breast cancer, with trastuzumab for all HER-2 overexpressors and random assignment to trastuzumab or not in HER-2 nonoverexpressors: final results of cancer and leukemia group B protocol 9840. J Clin Oncol. 26:1642-1649. doi:10.1200/JCO.2007.11.6699.

Shahriari-Ahmadi A, Arabi M, Payandeh M, Sadeghi M. 2017. The recurrence frequency of breast cancer and its prognostic factors in Iranian patients. Int J Appl Basic Med Res. 7:40-43. http://www.ijabmr.org/text.asp?2017/7/1/40/ 198521.

Shao -M-M, Chan SK, Yu AMC, Lam CCF, Tsang JYS, Lui PCW, Law BKB, Tan P-H, Tse GM. 2012. Keratin expression in breast cancers. Virchows Arch. 461:313-322. http://link.springer. com/10.1007/s00428-012-1289-9.

Shousha S. 2017. Breast pathology: problematic issues. 1st. Shousha S, Ed. Cham (Switzerland): Springer International Publishing; p. 204-208.

Simpson PT, Gale T, Reis-Filho JS, Jones C, Parry S, Sloane JP, Hanby A, Pinder SE, Lee AHS, Humphreys S, Ellis IO, Lakhani SR. 2005. Columnar cell lesions of the breast: the missing link in breast cancer progression? A morphological and molecular analysis. Am J Surg Pathol. 29:734-746. http://eutils.ncbi.nlm.nih.gov/entrez/ eutils/elink.fcgi? dbfrom $=$ pubmedandid $=15897740$ andret mode $=$ refand $\mathrm{cmd}=$ prlinks $\% 5$ n papers $3: / /$ publication $/$ uuid/89D52640-297C-4A38-9303-11B4905FB102.

Singhai R, Patil VW, Jaiswal SR, Patil SD, Tayade MB, Patil AV. 2011. E-Cadherin as a diagnostic biomarker in breast cancer. N Am J Med Sci. 3:227-233. doi:10.4297/ najms.2011.3227.

Slamon D, Leyland-Jones B, Shak S, Fuchs H, Paton V, Bajamonde A, Fleming T, Eiermann W, Wolter J, Pegram M, Baselga J, Norton L. 2001. Use of chemotherapy plus a monoclonal antibody against HER2 for metastatic breast cancer that overexpresses HER2. N Engl J Med. 344:783-792. doi:10.1056/NEJM200103153441101.

Slamon D, Eiermann W, Robert N, Pienkowski T, Martin M, Press M, Mackey J, Glaspy J, Chan A, Pawlicki M, Pinter T, Valejo V, Liu M-C, Sauter G, Minckwitz G, Visco F, Bee V, Buyse M, Bendahmane B, Tabah-Fish I, Lindsay M, Riva A, Crown J. 2011. Adjuvant trastuzumab in HER2-positive breast cancer. $\mathrm{N}$ Engl J Med. 365:1273-1283. doi:10.1056/NEJMoa0910383.

Soliman AA, Anis SE. 2014. Immunohistochemical expression of p21 in ductal carcinoma of the breast and its correlation with HER2/neu expression and hormonal status. Acad J Cancer Res. 7:98-108. https://www.idosi.org/ ajcr/7(2)14/6.pdf.

Striebel JM, Dacic S, Yousem SA. 2008. Gross cystic disease fluid protein-(GCDFP-15): expression in primary lung adenocarcinoma. Am J Surg Pathol. 32:426-432. http:// 
eutils.ncbi.nlm.nih.gov/entrez/eutils/elink.fcgi?dbfrom= pubmedandid $=18300807$ andretmode $=$ refand $\mathrm{cmd}=$ prlinks $\% 5$ Cnpapers $3: / /$ publication/doi/10.1097/PAS. 0b013e318157a5a6.

Tan PH, Sahin AA. 2017. Atlas of differential diagnosis in breast pathology. New York: Springer-Verlag. http://link. springer.com/10.1007/978-1-4939-6697-4

Tay TKY, Tan PH. 2017. Spindle cell lesions of the breast-an approach to diagnosis. Sem Diagn Pathol. 34:400-409. doi:10.1053/j.semdp.2017.05.012.

Thike AA, Cheok PY, Jara-Lazaro AR, Tan B, Tan P, Tan PH. 2010. Triple-negative breast cancer: clinicopathological characteristics and relationship with basal-like breast cancer. Mod Pathol. 23:123-133. doi:10.1038/modpathol.2009.145.

Tornos C, Soslow R, Chen S, Akram M, Hummer AJ, Aburustum N, Norton L, Tan LK. 2005. Expression of WT1, CA 125 and GCFFP-15 as useful markers in the differential diagnosis of primary ovarian carcinomas versus metastatic breast cancer to the ovary. Am J Surg Pathol. 29:1482-1489. doi:10.1097/01.pas.0000176429.88702.36.

Tot T. 2002. Cytokeratins 20 and 7 as biomarkers: usefulness in discriminating primary from metastatic adenocarcinoma. Eur J Cancer. 38:758-763.

Tot T, Tabár L, Dean PB. 2014. Practical breast pathology. 2nd ed. Thieme (Stuttgart): Germany; p. 134-136.

Tse GM, Ni YB, Tsang JYS, Shao MM, Huang YH, Luo MH, Lacambra MD, Yamaguchi R, Tan PH. 2014. Immunohistochemistry in the diagnosis of papillary lesions of the breast. Histopathology. 65:839-853. doi: $10.1111 /$ his. 12453 .

Tse GM. 2017. Papillary lesions of the breast. Diagn Histopathol. 24:64-70. doi:10.1016/j.mpdhp.2017. 12.005 .

Tse GMK, Lee CS, Kung FYL, Scolyer RA, Law BKB, Lau TS, Putti TC. 2002. Hormonal receptors expression in epithelial cells of mammary phyllodes tumors correlates with pathologic grade of the tumor: a multicenter study of 143 cases. Am J Clin Pathol. 118:522-526. doi:10.1309/ D206-DLF8-WDNC-XJ8K.

Tse GMK, Tan P-H, Lui PCW, Gilks CB, Poon CSP, Ma TKF, Law BKB, Lam WWM. 2007. The role of immunohistochemistry for smooth-muscle actin, p63, CD10 and cytokeratin 14 in the differential diagnosis of papillary lesions of the breast. J Clin Pathol. 60:315-320. http://www.pubmedcentral.nih.gov/articler ender.fcgi ?artid $=1860581$ andtool=pmcentrezandrender type $=$ abstract.

Tse GMK, Lui PCW, Vong JSL, Lau K-M, Putti TC, Karim R, Scolyer RA, Lee C-S, Yu AMC, Ng DCH, Tse AKY, Tan P-H. 2009. Increased epidermal growth factor receptor (EGFR) expression in malignant mammary phyllodes tumors. Breast Cancer Res Treat. 114:441-448. http://www.ncbi.nlm.nih.gov/pubmed/18443904.

Uchoa DM, Cruz DB, Schaefer PG, Pegas KL, Cambruzzi E. 2010. Myofibroblastoma arising in mammary hamartoma: a case report. Pathol Res Int. 2010:1-4. http://www.ncbi. nlm.nih.gov/pubmed/21151720.

Van ZA, Chb MB, Schneider JW, Chb MB, Pathology MA. 2016. Histological and immunohistochemical evaluation of sentinel lymph nodes in breast cancer at a tertiary hospital in the Western Cape, South Africa. S Afr Med J. 106:528-530.

Virk RK, Khan A. 2010. Pseudoangiomatous stromal hyperplasia: an overview. Arch Pathol Lab Med. 134:1070-1074.

Wang Z, Spaulding B, Sienko A, Liang Y, Li H, Nielsen G, Gong GY, Ro JY, Zhai QJ. 2009. Mammaglobin, a valuable diagnostic marker for metastatic breast carcinoma. Int J Clin Exp Pathol. 2:384-389.

Ward EM, DeSantis CE, Lin CC, Kramer JL, Jemal A, Kohler B, Brawley OW, Gansler T. 2015. Cancer statistics: breast cancer in situ. CA Cancer J Clin. 65:481-495. http://doi.wiley.com/10.3322/caac.21321.

Wei S. 2016. Papillary lesions of the breast: an update. Arch Pathol Lab Med. 140:628-643. doi:10.5858/arpa.20150092-RA.

Wen X, Cheng W. 2013. Nonmalignant breast papillary lesions at core-needle biopsy: a meta-analysis of underestimation and influencing factors. Ann Surg Oncol. 20:94-101.

Werling RW, Yaziji H, Bacchi CE, Gown AM. 2003. CDX2, a highly sensitive and specific marker of adenocarcinomas of intestinal origin: an immunohistochemical survey of 476 primary and metastatic carcinomas. Am J Surg Pathol. 27:303-310. doi:10.1097/00000478-20030300000003.

Whithaus K, Fukuoka J, Prihoda TJ, Jagirdar J. 2012. Evaluation of napsin A, cytokeratin 5/6, p63, and thyroid transcription factor 1 in adenocarcinoma versus squamous cell carcinoma of the lung. Arch Pathol Lab Med. 136:155-162. doi:10.5858/arpa.2011-0232-OA.

Wright C, Nicholson S, Angus B, Sainsbury JR, Farndon J, Cairns J, Harris AL, Horne CH. 1992. Relationship between c-erbB-2 protein product expression and response to endocrine therapy in advanced breast cancer. Br J Cancer. 65:118-121. http://www.scopus.com/inward/ record.url? eid $=2-s 2.0-0026502860$ and partner $I D=$ 40 andmd5=6d02690378861fe965d62615527c83b2.

Wu Q, Li J, Zhu S, Wu J, Chen C, Liu Q, Wei W, Zhang Y, Sun S. 2017. Breast cancer subtypes predict the preferential site of distant metastases: a SEER based study. Oncotarget. [Internet]. 8:27990-27996. http://www.oncotarget.com/full text/15856.

Xu XL, Chen SZ, Chen W, Zheng WH, Xia XH, Yang HJ, Li B, Mao WM. 2013. The impact of cyclin D1 overexpression on the prognosis of ER-positive breast cancers: a meta-analysis. Breast Cancer Res Treat. 139:329-339. doi:10.1007/s10549013-2563-5.

Yamauchi H, O’Neill A, Gelman R, Carney W, Tenney DY, Hösch S, Hayes DF. 1997. Prediction of response to antiestrogen therapy in advanced breast cancer patients by pretreatment circulating levels of extracellular domain of the HER-2/c-neu protein. J Clin Oncol. 15:2518-2525. doi:10.1200/JCO.1997. 15.7.2518.

Yang M, Nonaka D. 2010. A study of immunohistochemical differential expression in pulmonary and mammary carcinomas. Mod Pathol. 23:654-661. doi:10.1038/ modpathol.2010.38. 
Yeh I-T MC. 2008. Application of immunohistochemistry to breast lesions. Arch Pathol Lab Med. 132:424-431.

Yersal O, Barutca S. 2014. Biological subtypes of breast cancer: prognostic and therapeutic implications. World J Clin Oncol. 5:412-424. http://www.wjgnet.com/22184333/full/v5/i3/412.htm.

Youssef MMG, Cameron D, Pucher PH, Olsen S, Ferguson D. 2016. The significance of sentinel lymph node micrometastasis in breast cancer: comparing outcomes with and without axillary clearance. Breast. 30:101-104. doi:10.1016/j.breast.2016.09.005.
Zaha DC. 2014. Significance of immunohistochemistry in breast cancer. World J Clin Oncol. 5:382-392. http:// www.pubmedcentral.nih.gov/articlerender.fcgi?artid= 4127609andtool=pmcentrezandrendertype $=$ abstract.

Zámečník M. 2014. Gynecomastia with pseudoangiomatous hyperplasia and multinucleated giant cells in a patient without neurofibromatosis. Cesk Patol. 50:51-53.

Zhao L, Yang X, Khan A, Kandil D. 2014. Diagnostic role of immunohistochemistry in the evaluation of breast pathology specimens. Arch Pathol Lab Med. 138:16-24. doi:10.5858/arpa.2013-0455-OA. 